REVISTA DE DERECHO UNED, núm. 6, 2010

\title{
¿DE CUÁNDO ACÁ NOS VINO? LOPE DE VEGA Y EL TABÚ DEL INCESTO
}

\author{
ENRIQUE VIVÓ DE UNDABARRENA \\ Profesor Honorario de la UNED
}

Resumen: Lope de Vega obsesionado en su vida por el amor emparejado, aborda una vez más en la comedia «¿De cuándo acá nos vino?» la conquista amorosa a la que se colocan impedimentos que más bien se convierten en posibilidades. Nos presenta supuestos hipotéticos para las protagonistas de consanguinidad, aunque ninguno de ellos sea real, jugando con la posibilidad o no, de su dispensa canónica. Las prescripciones del Concilio de Trento concluido cuando Lope era estudiante, sobre la concesión de las dispensas de consanguinidad se habían suavizado no poco, convertiéndose en un fácil acceso al matrimonio; la comedia de Lope si no es una crítica directa a esta corruptela, sí es al menos la exposición de una situación, ya costumbre en una sociedad en la que bajo las apariencias de un rigor familiar para la mujer casadera, frecuentaba atajos que llevaban al matrimonio. La obra es una muestra de cómo el tabú de una unión incestuosa, mantenido inquebrantable cuando se trata de la línea recta y del segundo grado de la línea colateral, sin embargo por lo que hace a ulteriores grados va desvirtuándose y con ello la minusvaloración del matrimonio, como modo de extender los lazos de amistad en una sociedad más abierta que va alejándose de la consideración tribal.

Como comedia de costumbres despliega además la vida de aquella sociedad con importantes observaciones como la multiculturalidad, y la transformación de la misma con elementos (soldados de los Tercios, indianos, criadas moriscas, moscones y picaros) que recogiendo las influencias periféricas logran integrarse en el panorama diario. 
Palabras clave: Matrimonio con rapto. Incesto. Impedimento de consanguinidad. Linea recta y colateral. Segundo, tercero y cuarto grado de consanguinidad. Dispensa canónica.

Abstract: In «¿De cuando acá nos vino?,» Lope de Vega once again takes up the subject of romantic conquest troubled by apparent impediments which eventually turn out to be possibilities. The author speculates about blood relationships between the characters and the possibility of canonical dispensation.

The Council of Trent, whose final sessions took place when de Vega was a student, issued decrees on dispensation from consanguinity which gave way to marriage within close degrees of kinship. Although de Lope does not openly criticizes this situation, he exposes how, under the guise of family rigour, bachelorettes took advantage of the law to get married despite consanguinity.

Even though a union between first- and second-degree relatives was considered incestuous hence social taboo, marriage within subsequent degrees of kinship was socially accepted.

«¿De cuando acá nos vino?» is a comedy of manners which provides a broad picture of contemporary society with its multicultural character. De Vega shows how soldiers, adventurers, Moorish maidservants and rogues gradually become part of the social panorama in the $17^{\text {th }}$ century Spain.

Sumario: I. INTRODUCCION: Lope representa en su vida sus dramas amorosos: Herencias paternas. Amoríos y resentimientos. Procesado. Matrimonio con rapto. Desterrado. Segundas nupcias y nuevos amoríos. Su ordenación y el Duque de Sessa. Postrer amorío. Cuando cae el telón de la vida. EsTRUCTURA DRAMATICA: Redacción y autoría. Estreno y representaciones. Transformación y originalidad. Influencia literaria. EL IMPEDIMENTO DE CONSANGUINIDAD Y SU DISPENSA: La legislación del «Corpus Iuris Canonici». La dispensa de la consanguinidad en el Concilio de Trento.-II. EN ESCENA: La galería de personajes. Ambiente marco. Las acciones secundarias. ACTO PRIMERO. «Dramatis personae»: El alférez Leonardo; Bárbara, Ángela y sus pretendientes; el soldado Beltrán. AcTO SEGUNDO. Una carta que abre puertas y corazones: Huéspedes de doña Bárbara. Enamoramiento de Doña Bárbara y celos de Ángela. Enfrentamiento entre ellas. Cruel engaño de la madre y desolación de la hija. Perplejidad del alférez. Acto terCERo. Desenredando el desenlace: Llegada desconcertante del Capitán Fajardo. El hijo fingido. El arbitraje del Capitán. Las dos bodas solución paródica sin fraude y sin atajos.-III. BALANCE Y CONCLUSIONES: Las dis- 
¿DE CUÁNDO ACÁ NOS VINO? LOPE DE VEGA Y EL TABÚ DEL INCESTO

pensas canónicas. Las causas. Una sutil actitud con lenguaje técnico teatral. Dieciseis referencias expresas a la «dispensación». Conclusiones.

\section{INTRODUCCION}

Una comedia clásica, por más que sea de un género intrascendente como es el "de capa y espada», es por sí misma comunicativa, de ella puede llegar al espectador de todo, y no simplemente los sentimentos obvios de un libreto emotivo. Y máxime cuando la trama que se plantea como en el caso, es particularmente compleja ${ }^{1}$. Al hilo de un enredo amoroso con que trata de divertir a su público, el autor se plantea reflejar diversos aspectos de su mundo de distintos órdenes.

Hemos intentado ver en las costumbres y vida de aquella sociedad, un punto de vista sutil desde el ordenamiento legal y jurídico, testimonio de caminos, más bien atajos, usados a veces no rectamente, para llegar al matrimonio.

\section{I.1. Lope representa sus comedias en su vida}

A Lope «monstruo de la naturaleza» por su desmedida personalidad en su obra literaria y en su manera de conducirse ${ }^{2}$, se le ha podido clasificar como "caso psicológico de genio», en cuya vida se reproducen las características del hombre renacentista y del barroco, que lleva a cabo en su obra las tensiones de amor apasionado y de conflicto, junto con la religiosidad más ferviente: Sus escritos son al mismo tiempo que el reflejo de una sociedad, su autorretrato; junto a sus cartas (un tesoro no explotado), las vivencias en sus obras, de sí mismo y de sus pasiones en la sociedad que lo encarna ${ }^{3}$.

\section{I.1.A. Herencias paternas}

Se sabe que Félix de Vega, padre de Lope, bordador de profesión, llegó de la Montaña Cántabra, a Madrid en 1561, atraído quizá por las posibilidades de la recién estrenada capitalidad de la Villa; Lope aclarará un día que su padre vino a Madrid en una aventura

\footnotetext{
1 RAFAEL RODRIGUEZ, “¿De cuándo acá nos vino?» en Cuadernos pedagógicos del Teatro Nacional. Entrevista al director de escena, n. 32, p. 56.

2 MIGUEL DE CERVANTES, Ocho Comedias y ocho Entremeses nuevos, Prólogo.

3 ANGEL VALBUENA PRAT, Historia de la Literatura Española, vol. II, Barcelona, 1946, p. 1
} 
apasionada de la que le rescató su mujer Francisca Fernández ${ }^{4}$. Luego el esposo y padre en su vida se dio a la piedad y a la caridad en los hospitales, anticipándose en él una mezcla de afanes de aventura amorosa y religiosidad, que habría de repetirse en su hijo con la intensidad de un genio ${ }^{5}$.

Instalados en la calle Mayor, junto a la Puerta de Guadalajara, zona de Gremios como lo acredita la calle de Bordadores que persiste, nació Lope el 25 de noviembre de 1562; fue bautizado en la parroquia de San Miguel, siendo el mayor de cinco hermanos ${ }^{6}$.

\section{I.1.B. Desorganizado niño prodigio}

Cuenta su discípulo y primer biógrafo que a los cinco años entendía el latín y que dictaba sus primeros versos a otros niños mayores por no saber todavía escribir ${ }^{7}$. Hizo estudios de Gramática y Retórica en el Colegio de la Compañía de Jesús después Colegio Imperial ${ }^{8}$. Dentro de los colegios de los Jesuitas se cultivaba el teatro escolar, representado en las festividades; Lope, colegial, no dejaría de intervenir, despertándose quizá así su orientación e iniciándose en este período su afán dramático, pues según su propio testimonio, a los doce años escribe comedias 9 .

4 LOPE DE VEGA, Epístola a Amarilis Indiana: Siguióle hasta Madrid, de celos ciega,/su amorosa mujer, porque él quería / otra española / Hicieron amistades, y aquel día Ifue la paz de su celosa fantasía. / En fin, por celos soy: / que haber nacido de tan inquieta causa fue portento.

${ }_{5}$ En la vida del Beato Bernardino de Obregón se menciona su gran amistad con el padre de Lope, siguiéndole en el ejercicio de caridad sirviendo a los pobres en el Hospital del Buen Suceso acompañándole sus hijos. En cuanto a sus aficiones literarias su hijo en el Laurel de Apolo lo pondera diciendo que me enseñaste versos en la cuna.../basta saber que en el Parnaso estuvo/habiendo hallado yo los borradores./Versos eran a Dios, llenos de amores.

6 De la casa donde nació dirá Lope: pared y media de donde puso Carlos V la soberbia de Francia entre dos paredes, es decir, frontera a la Torre de los Lujanes, prisión de Francisco I.

7 Debió asistir a la escuela del poeta y músico Vicente Espinel, según el soneto que le dedicó: Aquesta pluma, célebre maestro / que me pusisteis en las manos, cuando / los primeros caracteres firmando / estaba, temeroso y poco diestro. Siempre le citó con veneración; así en El laurel de Apolo, donde le llama «único poeta latino y castellano de estos tiempos», o en el prólogo a La viuda valenciana, donde le llama "padre de la música».

8 JUAN PÉREZ DE MONTALBÁN,. Fama postuma a la vida y muerte del Doctor frey Lope Felix de Vega Carpio, Madrid, 1636.

${ }^{9}$ LOPE DE VEGA, Arte nuevo de hacer comedias: Yo las componía de once y doce años / de a cuatro actos y de a cuatro pliegos. 
Pero al mismo tiempo Lope se inicia en sus aventuras. Muerto de repente su padre en 1578, deseoso de conocer mundo, "se desgarró» de casa en compañía de un amigo, llegando hasta Astorga ${ }^{10}$.

Puesto al servicio de D. Jerónimo Manrique, Inquisidor General y obispo de Ávila, al que se ganó con unas églogas y una comedia ${ }^{11}$, debió ayudarle para que hiciese estudios en la Universidad de Alcalá de Henares ${ }^{12}$. Nada se sabe con certeza de estos estudios universitarios iniciados cuando tiene 15 años, mas no debió de realizarlos con suficiente dedicación, pues cursando cuatro años (1577-1581), no logra ningún título ${ }^{13}$. Sus devaneos y conducta desordenada le hacen poco apto para el sacerdocio. Su protector deja de costearle los estudios y para ganarse la vida tiene que trabajar como secretario de aristócratas, y escribir comedias o piezas de circunstancias.

\section{I.1.C. Soldado y poeta}

En 1583 se alista en la Marina y pelea en la batalla de la Isla Terceira, a las órdenes de su futuro amigo don Álvaro de Bazán, marqués de Santa Cruz. El 15 de septiembre, a los dos meses la escuadra regresa a Cádiz, terminando la anexión de Portugal a la Corona de Felipe $\mathrm{II}^{14}$.

10 PÉREZ DE MONTALBÁN: De esta precoz aventura que se refleja en La Dorotea, dice que arrepentidos, de regreso a su casa por Segovia, un alguacil los reintegró a su domicilio.

11 A. ZAMORA VICENTE, loc. cit. p. 39: Se trata de La Pastoral de Jacinto, la primera de tres jornadas, que fue muy aplaudida e instauró un nuevo género porque hasta entonces las comedias consistían sólo en un díalogo de cuatro personas y no pasaban de tres pliegos.

12 LOPE DE VEGA, La Filomena: Crióme don Jerónimo Manrique, / estudié en Alcalá, bachilleréme, / y aun estuve de ser clérigo a pique. / Cegome una mujer, aficionéme, / perdóneselo Dios. De D. Jerónimo Manrique dirá que fue uno de los príncipes que ha tenido esa clara sangre en el estado eclesiástico, pues con tenerle no olvidó las armas en la batalla naval de Lepanto, siendo su vicario general, por la Santidad de Pio $V$.

13 LOPE DE VEGA, La Dorotea, IV: Los cartapacios de las liciones me servían de borradores para mis pensamientos, y muchas veces las escribía en versos latinos o castellanos. Comencé a juntar libros de todas letras y lenguas, que después de los principios de la griega y ejercicio grande de la latina, supe bien la toscana, y de la francesa tuve noticia.

${ }^{14}$ La empresa militar dejó hermosas huellas en el teatro de Lope, así en «El galán escarmentado", donde se incluye una minuciosa narración de la pelea con movido lenguaje marinero. 
Tiene 21 años y es poeta estimado; hay que suponer que ha escrito ya con sobresaliente calidad para ser citado como uno de los ingenios distinguidos ${ }^{15}$.

\section{I.1.D. Amoríos y resentimientos. Procesado y encarcelado}

Elena Osorio fue su primer gran amor; «Filis» de sus versos, separada de su marido el actor Cristóbal Calderón, hija del famoso autor teatral Jerónimo Velázquez de la calle Lavapiés. Lope de Vega pagaba sus favores con comedias para la compañía de su padre. Pero en 1587 Elena se amarteló con un sobrino del poderoso cardenal Granvela, por lo que Lope despechado hizo circular contra ella y su familia libelos injuriosos ${ }^{16}$.

Otra de las causas de la saña de Lope menos romántica pudo ser que Jerónimo Velázquez al marchar a Sevilla en 1587, no le pidió comedias para representarlas allí, lo que debió doler a Lope ${ }^{17}$.

Un dictamen judicial lo hizo preso en el corral de Comedias de la Cruz. Reincidió desde la cárcel con sus escritos y un segundo proceso judicial fue más tajante desterrándolo ocho años de la Corte y dos años del Reino de Castilla, con amenaza de pena de muerte si desobedecía la sentencia ${ }^{18}$.

\section{I.1.E. Matrimonio con rapto}

Para entonces ya se había enamorado de Isabel de Urbina, en sus versos «Belisa» (isa-bel), cuyo padre había sido regidor de Ma-

15 M. CERVANTES, La Galatea: (1585), en el canto de Calíope: Muestra en un ingenio la experiencia / que en años verdes y en edad temprana / hace su habitación así la ciencia, / como en la edad madura, antigua y cana: / Mas si acaso a sus oídos llega / que lo digo por vos, Lope de Vega.

16 LOPE DE VEGA, Una dama se vende a quien la quiera / en almoneda está. ¿Quieren comprarla?/ Su padre es quien la vende, que, aunque calla, / su madre la sirvió de pregonera... De su hermano Damián abogado de cierta nombradía en uno de los poemas le acusaba de ignorante, diciendo que por ser hijo de comediante se le debía negar dedicarse a la abogacía.

17 Velázquez era entonces el autor (empresario teatral) más importante de Madrid y Lope tuvo que buscar a Gaspar de Porres para que se las representara, que entonces no podía compararse con Velázquez. Lope dirá «que si yo le diera mis comedias, no se querellara de mí».

18 A. TOMILLO y C. PÉREZ PASTOR, Proceso de Lope de Vega por libelos contra unos cómicos, Madrid 1901: «Los cuatro años de destierro de esta corte sean ocho, demás de los dos del reino; no los quebrante so pena de muerte los del reino». 
drid, y ante la posibilidad de que la familia no accediese al matrimonio, la raptó con su consentimiento, casándose por poder una vez retirada la denuncia de los padres, el 10 de mayo de 1588 en la parroquia de San Ginés ${ }^{19}$.

Un par de semanas después de la boda reanudó al parecer su carrera militar, alistándose en la Armada Invencible, a bordo del galeón San Juan. En diciembre de 1588 desembarcaba en Cádiz después de la derrota y dispersión de la gran escuadra, en la que había muerto en sus brazos en acción de guerra su hermano Juan.

\section{I.1.F. Desterrado en Valencia}

Se establece con su mujer Isabel de Urbina en Valencia, donde contacta con los dramaturgos de la llamada Academia de los Nocturnos $^{20}$. Siguió escribiendo comedias que enviaba a Madrid a su nuevo empresario Gaspar de Porres.

En 1590, al cumplirse los dos años de destierro del reino de Castilla, Lope de Vega se trasladó a Toledo y allí sirvió de secretario al duque de Alba, incorporándose en 1592 como gentilhombre de cámara a la corte ducal de Alba de Tormes, donde en el otoño de 1594, murió de sobreparto Isabel de Urbina. En diciembre de 1595, abandonando el servicio de Alba, volvió a Madrid al ser perdonado por Jerónimo Velázquez ${ }^{21}$.

\section{I.1.G. Segundas nupcias y nuevos amorios}

En 1598 se casó con Juana de Guardo, hija de un adinerado abastecedor de carne y pescado de la Corte ${ }^{22}$. Tuvo con ella, un hijo muy querido, Carlos Félix, y tres hijas.

19 Inventario de las causas criminales: «Lope de Vega y Juan Chaves alguacil, por el rapto de doña Isabel de Alderete». Es la huella que ha dejado en el Registro el proceso seguido que se ha perdido.

20 Eran miembros de la misma el canónigo Francisco Agustín Tárrega, el secretario del Duque de Gandía Gaspar de Aguilar y Guillén de Castro.

${ }^{21}$ FRANCISCO FLORIT DURÁN, La recepción de Lope en 1935, en «Anuario Lope de Vega", VI, 2000, p. 120: El 28 de marzo de 1595, el padre de Elena Osorio firma la petición de apartamiento de la querella, pocos meses antes de haberse cumplido la sentencia, posiblemente por el deseo de incrementar su repertorio teatral,

${ }^{22}$ Hubo burlas de algunos que como Luis de Góngora, pensaban que Lope que tenía 38 años, se había casado por dinero con aquella mujer vulgar, ya que no eran amores precisamente lo que le faltaba. 
Enamorado de Micaela de Luján, casada con otro representante que marchó a Perú, bella comedianta, pero inculta pues no sabía firmar; retirándola de la escena, tuvo de ella cinco hijos, entre éstos dos de sus predilectos, Marcela (1606) y Lope Félix (1607), hasta 1608 , en que rompe el trato perdiéndose su rastro. Mantiene relaciones simultáneas dividido entre dos hogares y un número indeterminado de amantes, la mayoría actrices ${ }^{23}$; en dicha lista figura Jerónima de Burgos, actriz y mujer del «autor» Pedro Valdés, la que fuera de su relación profesional y de amistad, no debió de pasar de ser «una amante pasajera ${ }^{24}$.

\section{I.1.H. «Parva propria magna». Muertes cercanas}

En 1609 leyó y publicó Arte nuevo de hacer comedias, rebelión literaria frente a los preceptos neoaristotélicos.

En 1610 establecido el matrimonio definitivamente en Madrid, compró en la calle de Francos una casa con su huertecillo donde residirá ya hasta morir ${ }^{25}$ y donde debió escribir De cuándo acá nos vino, estrenada en $1615^{26}$. Parecía llegada con este asentamiento la calma doméstica, pero la muerte y la desgracia perturbarán su vida ${ }^{27}$.

${ }^{23}$ El proceso legal que en 1596 se le abrió por amancebamiento con Antonia Trillo, actriz viuda, da fe de sus múltiples amoríos.

${ }_{24}$ MIMMA DE SALVO, Notas sobre Lope de Vega y Jerónima de Burgos: estado de la cuestión. Valencia 2009. Es más famosa por haber sido esporádica amante de Lope que por ser mujer de uno de los más importantes «autores» de comedias del Siglo de Oro. La primera noticia que de ella tenemos es la de haber sido madrina de Lopito hijo de Lope de Vega y Micaela de Luján, el 7 de febrero de 1607 en la Parroquia de San Sebastián. No se tienen noticias de Jerónima hasta 1611, menudeando luego las referencias en el epistolario al de Sessa. Es «la amiga del buen nombre» a la que ahora se le llama Gerarda. Después de un tiempo de buen trato una carta de 25 de julio de 1615 nos muestra la ruptura con Valdés y con Jerónima a la que en adelante se le apoda "Pandorga», atacándola porque le ha calumniado ante el Duque. En esta carta hay una referencia a que la compañía de Valdés desamparada de Lope está dedicada a Tirso de Molina, representando Don Gil de las calzas verdes «desatinada comedia del Mercenario». Después de reconocer haberse acostado con Jerónima aun cuando no nos dice cuando , es en esta carta apasionada en la que la presenta haciéndolo en una misma noche con varios hombres seguidos. Posteriores cartas seguirán reflejando su animosidad contra Jerónima.

${ }^{25}$ En el dintel de la puerta se puede leer, «Magna aliena parva, parva propria magna».

26 MAR ZUBIETA, ¿De cuándo acá nos vino? Cuadernos pedagógicos, 32, Teatro Clásico, p. 16.

27 LOPE DE VEGA, Mas tengo un bien en tantos disfavores, I dos libros, tres pinturas, cuatro flores./ Que mi jardín tiene sólo dos árboles, diez flores / dos parras y un naranjo. 
En 1612 su hijo Carlos Félix de siete años, muere de fiebres ${ }^{28}$; y al año siguiente su esposa Juana de Guardo después de constantes enfermedades, al dar a luz a Feliciana. La muerte de sus seres queridos le va a sumir en profundo sufrimiento que le hará refugiarse en la piedad. Lope en su soledad busca con qué llenar y dar vida a su casa y se trae los últimos hijos habidos de Micaela, a Marcela de ocho años que estará con él hasta los diecisiete cuando profese en el convento vecino de las Trinitarias, y a Lope Felix.

En 1613, Lope se une al séquito de Felipe III en un viaje a Segovia, Burgos y Lerma. En él figura la comedianta y vieja amiga Jerónima ${ }^{29}$.

\section{I.1.I. Su ordenación y la correspondencia del Duque de Sessa}

Desde 1605 estaba al servicio de Luis Fernández de Córdoba y de Aragón, duque de Sessa, como secretario y consejero de sus devaneos, con el que mantendrá toda su vida relación estrecha no siempre recomendable ${ }^{30}$. Además del mecenazgo, Lope obtuvo por mediación del Duque en 1608 el cargo honorífico de «familiar del Sto. Oficio de la Inquisición» ${ }^{31}$.

En 1614 con 52 años toma la decisión trascendental de hacerse sacerdote $^{32}$. Lope ordenado de menores a principios de marzo de 1614, poco después marchó a Toledo diócesis a la que pertenecía, para poder recibir allí las órdenes mayores ${ }^{33}$. En carta del 15 de marzo noti-

${ }^{28}$ Había escrito para Carlos Felix «Los pastores de Belén» que se edita en 1612. De su enfermedad dice al Duque: "Carlitos está con tercianas dobles, muy trabajoso; no come nada; si allá hay alguna jalea mande V. E. a Bermudez que la envíe».

${ }_{29}$ MIMMA DE SALVO, loc. cit. Jerónima va con la compañía de su marido en la comitiva que acompaña al Rey para representaciones teatrales bajo la dirección de Valdés y Lope. En carta de 23 de septiembre de 1613 escribe: «Yo Señor, lo he pasado bien con mi huéspeda Jerónima». En la licencia de «La Dama boba» obra que se dice regalada a Jerónima, en la relación de los actores que la estrenaron, figura escrito de la mano de Lope que Jerónima representaría el papel de Nise «la culta».

${ }^{30}$ F. FLORIT DURÁN, loc. cit. Acusa a esta relación de hundir a Lope en las mayores bajezas, planteándole profundos problemas de conciencia, a la vez que pone de relieve la generosidad del mecenas.

31 A. GLZ. DE AMEZUA, Lope de Vega en sus cartas, Madrid, 1936-1947. Ha recogido en cuatro volúmenes la correspondencia con el Duque de Sessa.

32 LOPE DE VEGA, Aunque por tanta indignidad cobarde,/ el ánimo dispuse al sacerdocio./ Dejé las galas que seglar vestía / Ordenéme, que importaba / el ordenarme a la desorden mía.

33 A. GLZ. DE AMEZUA, loc. cit. Doce cartas de Lope al Duque de Sessa escritas durante aquella estancia en Toledo, nos permiten seguir día por día aquellos pasos. 
fica al Duque su ordenación de subdiácono, mencionando a Jerónima Burgos que le ha hospedado ${ }^{34}$.

El 21 de marzo al anunciar su próxima ordenación de diácono, expresa su deseo de que sea el Nuncio quien le ordene de presbítero en Madrid $^{35}$; al mismo tiempo sigue con sus noticias de Jerónima en cuya casa continúa ${ }^{36}$. La carta del 23 de marzo nos aclara la protección con que contaba en Toledo ante el Arzobispo y nos detalla el empleo de su tiempo en esta dilatada estancia ${ }^{37}$.

El 24 de mayo de 1614 finalmente se ordena de sacerdote. Dice su primera Misa en el Convento de los Carmelitas descalzos, orden a la que pertenece su confesor, Fray Martín de San Cirilo, en la iglesia donde poco tiempo antes había enterrado a su mujer ${ }^{38}$.

34 LOPE DE VEGA, 15-III-1614, «Llegué, presenté mis dimisorias al de Troya, que así se llama el Obispo, y diome Epístola; para que V. E. sepa que ya me voy acercando a capellán suyo; y sería de ver cuán a propósito ha sido el título, pues sólo por Troya podía ordenarse hombre de tantos incendios, mas tan cruel como si hubiera sido el que metió en ella el caballo, porque me riñó porque llevaba bigotes, y con esta justa desesperación yo me los hice quitar; de suerte que dudo que V. E. me conozca; aunque no me atreveré a volver a Madrid tan rapado; aquí me ha recibido y aposentado la señora Gerarda con muchas caricias. Está mucho menos entretenida y más hermosa. Besa los pies de V. E. y me manda le escriba mil recados. Téngalos V. E, Señor, por recibidos».

${ }^{35}$ LOPE DE VEGA, 19-III-1614, «Mi vida en Toledo es ir y venir a solicitar al Prelado para que me dé estas dimissorias, supliendo a tiempo; y dende que me ordené de Epístola. Deseara no se olvide V. E. de hablar de mí a Monseñor Nuncio y de decirle que por estar en esta ocupación no he vuelto a servirle como me lo mandó aquella noche».

36 LOPE DE VEGA, 21-III-1614, "Creo iré ordenado de Evangelio, con que Monseñor Nuncio podrá darme el último grado en llegando las temporas. Esta señora huéspeda tiene salud y desea a V. E. todo bien, según me ha significado, deseando ser compadre suyo después del Corpus.» Jerónima iba a ser madrina con el Duque de su hija Feliciana.

37 LOPE DE VEGA, 23-III-1614, «Lo cierto es que yo querría concluir, Sr. Ex., con mis órdenes; y pues ya tengo Epístola, no dilatar las demás, por no estar en este cuidado: dos vezes he hablado al Cardenal, y la última le di un memorial, que hoy espero. El Deán y Arcediano desta Santa Iglesia son, por antiguo conocimiento, tan inclinados a mi protección, que quieren solicitar esta gracia, y assí no escuso de intentarlo aunque sea con alguna dilación de mi partida. Mi vida es ésta y los pasos, de la posada a la iglesia; rezar dos horas que ya me obligan, y a la noche hablar un rato, mientras llega la del sueño, con algún amigo; también me divierto de mis tristezas con la amiga del buen nombre, que ya tiene esto de gusto para V. E. Ella está tan agradecida a la merzed que V. E. la hace, que viéndome con cuidado de enviarle una anguila, me le tomó del pensamiento, y con alguna solicitud halló la que lleva ese criado suyo».

38 LOPE DE VEGA, Epístola al Dr. Matías de Porras: La epístola solícito negocio,/ dalmática evangélica me visto, / humilde adquiero la cruzada estola / y la suprema dignidad conquisto. 
La expresión literaria de esta etapa son las numerosas obras devotas que empieza a componer; entre ellas las Rimas sacras, publicadas en 1614 y dedicadas a su confesor.

\section{I.1.J. Actividades y dificultades del eclesiástico}

Dos años, 1614 y 1615, dura en Lope su caminar fiel a su nuevo estado:

En 1614, Lope figura en el Tribunal de calificación del certamen celebrado con motivo de la beatificación de Santa Teresa ${ }^{39}$.

El 16 de junio de dicho año se bautiza a su hija Feliciana ${ }^{40}$.

En 1615 viajó a Ávila con el propósito de conseguir una capellanía, instituida por su antiguo señor y protector, el obispo Manrique de Lara $^{41}$.

Pronto sin embargo se presentan las complicaciones:

Sigue manteniendo el trato con la escena y la gente de teatro, como revelan sus cartas al Duque de Sessa, al que continuaba redactándole sus cartas de amor, entregado a tercerías amorosas a su favor, como en el caso de Jerónima Burgos ${ }^{42}$. El confesor del nuevo sacerdote consideraba gravísimo pecado este menester de secretario en aquellas mediaciones pecaminosas y le prohibió ocuparse de ello; es significativo el escrito que a últimos de junio de 1614 remitió Lope al Duque ${ }^{43}$.

39 El certamen se celebró en el Carmen Descalzo de Madrid, y en él tomaron parte entre otros Cervantes y Vicente Espinel.

40 Sorprende el retraso del bautismo, aunque es de suponer que en las circunstancias en que nace pudieron haberle dado en su día la llamada "agua de socorro». En los repetidos atrasos de la fecha del bautismo se advierte el interés de Lope para que Jerónima sea madrina con el Duque, que no se consigue por los compromisos teatrales de la actora, lo que parecía gestión para dar ocasión de un mayor avenimiento de la actora con el noble.

${ }^{41}$ LOPE DE VEGA: "Yo salí con ánimo de estar en Ávila dos días, y llegado allá, me advirtieron de que podía pretender una de las Capellanías que instituyó el Obispo mi Señor, de Santa memoria, prefiriendo a sus criados y porque no ha quedado otro que sea Sacerdote más antiguo; hiçe la diligençia, oré en el Cabildo como un Demóstenes, honrándome mucho, y mandaron hacer la ynformaçión, en que se gastó más tiempo que yo pensaba y quisiera».

${ }^{42}$ En sus cartas de este tiempo vemos que Lope trata de ganarse a Gerarda para que dé sus favores al Duque enemistado con ella por haberlo desairado en un coqueteo.

${ }^{43}$ LOPE DE VEGA: "Que como cada día confiesso este escrivir estos papeles, no quisieron el de S. Juan absolverme si no daba la palabra de dexar de hacerlo; y me aseguraron que estaba en pecado mortal; heme entristecido de suerte que creo no me huviera ordenado si creyera que havía de dexar de servir a V. E. en alguna cosa, mayormente en las que son tan de su gusto». 
El Duque por su parte, proporcionó a Lope un beneficio en Alcoba, en sus tierras de Córdoba, y sin duda por su intervención Lope lograba el nombramiento de Procurador Fiscal de la Cámara Apostólica del Arzobispado de Toledo, tomando posesión a finales de $1616^{44}$.

En 1615, la corte marchó para la unión matrimonial de la infanta Ana de Austria, hija de Felipe III, con Luis XIII de Francia, y la del Príncipe Felipe con Isabel de Borbón, hermana del rey francés. El duque de Lerma fue enviado por Felipe III a la raya del Bidasoa, para que trajese desde allí a la infanta francesa y llevase a la española. En el séquito de Lerma, iba Sessa y con él Lope de Vega como capellán que le acompaña ${ }^{45}$.

\section{I.1.K. Su postrer amorío}

En 1616 Lope de Vega perdidamente enamorado, inicia con Marta de Nevares una relación "sacrílega» dada su condición de sacerdote $^{46}$. Lope vive entonces la parte más dramática de su existencia ${ }^{47}$.

${ }^{44}$ LOPE DE VEGA: «Haya de saber el Duque mi Señor, que hoy vino a mi casa su secretario con el Auditor, y oyeron missa en este oratorio: diome el tal secretario la provisión de Procurador fiscal de la Cámara apostólica, officio de más consideración que el que le pidió V. E.; estoy contentíssimo, y desde aquí beso los pies del Almirante de Nápoles, mil veces, por la intercesión». Y tal vez referido a dicho nombramiento escribe: "Señor mío: mucho me duelen los trabajos de V. E: como no puedo ayudarlos, no tengo que ofrezerlos: no soy letrado, pero soy clérigo; mientras ellos busquen leyes en sus Bártulos, buscaré yo en mi breviario y Missal oraciones; que bien suele valer más que un párrafo, un Quaesumus omnipotens Deus».

45 LOPE DE VEGA: «Tengo de vivir tan retirado, que aun los ojos que Dios hizo para ver, no se alçen de la tierra. Viniendo a lo que ymporta a la jornada advierta V. E. Señor, que yo para mí no hubiera menester nada; pero todos saben ya que voy sirviendo de capellán a V. E. Sotanilla y herreruelo podrán ser de qualquier seda negra aforrándolos, la sotana en bayeta y el herreruelo en felpa, porque entiendan Lerma y eçéteras que me lleba V. E. y pueda sin vergüenza parecer donde hubiere de ser preciso el hallarnos juntos. V. E. mande que vayan de su oratorio dos casullas, cáliz y lo demás necessario para que con toda autoridad se diga missa, y aquellos señores vean que se sirve V. E. hasta en las cosas del altar con cuidado y grandeza».

46 CASIMIRO MORCILLO, Lope de Vega Sacerdote, Madrid 1934. Frente a Rennert y Castro, sostiene la idea de que Lope se hizo sacerdote no por un impulso momentáneo y frívolo. Entrambasaguas se refiere a un lento proceso psicológico que le llevó a ordenarse de sacerdote, que fue calando en el alma del poeta, con un firme deseo, en un afán sincero.

47 Lope escribiendo en 1616: "Yo he nacido en dos extremos, que son amar y aborrecer; no he tenido medio jamás... Yo estoy perdido, si en mi vida lo estuve, por alma y cuerpo de mujer, y Dios sabe con qué sentimiento mío, porque no sé cómo ha de ser ni durar esto, ni vivir sin gozarlo». 
$\mathrm{Al}$ adoptar la resolución de abrazar el estado de sacerdocio, ¿contó con sus fuerzas? ${ }^{38}$. Hay que tener en cuenta que el Fénix luchó toda su vida para vencer sus flaquezas, hasta el punto de que hacia el final de sus días se entregó arrepentido a purgar con penitencias corporales sus pecados anteriores ${ }^{49}$.

\section{I.1.L. Cuando cae el telón de la vida}

Lope de edad avanzada recibió honores del Rey y del Papa Urbano VIII que le nombró Doctor en Teología y le honró con la encomienda de San Juan acompañando desde entonces a su nombre el tratamiento de «Frey ${ }^{50}$. Pero sus últimos años los infortunios lo entristecieron ${ }^{51}$. Sólo Marcela, hija natural suya, monja trinitaria le sobreviviría ${ }^{52}$.

Lope de Vega se sintió enfermo en agosto de 1635. El 25 aún dijo misa en su oratorio, regó su huerto y trabajó en su estudio; asistió resfriado por la tarde a un acto, donde sufrió un desmayo llevándole en una silla a su casa. El domingo día 26 recibió los sacramentos y firmó su testamento. Al día siguiente perdida la facultad de hablar, muere besando un crucifijo, rodeado de numerosos amigos, entre ellos el Duque de Sessa. Una inmensa muchedumbre acudió al entierro, que pasó delante del convento de las Trinitarias para que su hija Marcela diera el postrer adiós al poeta. Fue enterrado en la Iglesia de San Sebastián de la calle de Atocha ${ }^{53}$.

48 CAYETANO ALBERTO DE LA BARRERA, Nueva biografía de Lope de Vega. Madrid 1973. Inserta en el tomo primero de la gran edición de las obras del Fénix publicadas por la Real Academia.

49 F. FLORIT DURÁN, La recepción de Lope en 1935: Ideología y Literatura, en «Anuario Lope de Vega», VI, p. 120.

50 Lope había dedicado al Pontífice en 1627 la «Corona trágica», poema sobre la vida de Maria Estuardo, reina martir de Escocia.

51 Sufrió que Marta se volviera ciega en 1626, y muriera loca en 1628. Lope Félix, su hijo y de Micaela de Luján se ahogaría pescando perlas en 1634 en la isla Margarita. Su querida hija Antonia Clara su secretaria en la vejez, fue secuestrada por su novio. Feliciana, su única hija legítima, para entonces, había tenido dos hijos: una se hizo monja y el otro fue capitán que muere en Milán al servicio del rey.

52 En la biografía de Marcela, manuscrita de las monjas, se dice que Lope en los últimos años de su vida iba a celebrar Misa a su Iglesia.

53 A. ZAMORA VICENTE, loc. cit., p. 77. 


\section{I.2. Datos y consideraciones sobre esta comedia}

\section{I.2.A. El título}

Resulta un tanto original y de no inmediata comprensión, pero coloquialmente expresivo, siendo por otra parte poco corriente que el título de una comedia sea una locución interrogativa; con ello desde el primer momento captamos al Lope de la «variedad, cantidad y libertad» que trata de alejarse de la senda de tópicos y modas del teatro del Siglo de Oro.

Su significado lo hizo más directamente comprensible Agustín Moreto cuarenta años después, al refundir a su gusto esta comedia de Lope con el título también en fórmula popular De fuera vendrá. En 1955 un polifacético hombre del espectáculo, José María de Arozamena, ve en ella las características adecuadas para transformarla en una comedia lírica con música del maestro Joaquín Rodrigo, dándole el título poco original de El hijo fingido ${ }^{54}$.

Para Rafael Rodríguez director de esta Representación, el sentido de la obra iniciado en el título es ¿de cuándo acá nos vino a Madrid, a España, todo aquello que nos ha transformado? ${ }^{55}$

\section{I.2.B. Redacción y autoría}

Publicada la comedia ¿De cuándo acá nos vino? por primera vez en la «Parte veinticuatro» de las comedias de Lope de Vega en $1633^{56}$, gracias a las escrituras notariales halladas, sabemos que Valdés, autor teatral estaba ya en posesión de ella el 31 de octubre de $1614^{57}$. Es importante señalar que hacía poco, el 24 de mayo de 1614 Lope de Vega se había ordenado sacerdote.

A pesar de carecer de firma, el manuscrito conservado de la Co-

54 El resultado es un híbrido, adornándose el argumento de ¿De cuándo acá nos vino? con pasajes de otras comedias de Lope.

55 El que en pleno siglo XX, se adaptase al género de la zarzuela, era muestra de que el tema no había perdido actualidad.

56 GAVELA DÉLIA, Lope de Vega: “¿De cuándo acá nos vino? en Criticón, 86, 2002, p. 272. Tesis doctoral Universidad Autónoma de Madrid (1-VII-2002).

57 FRANCISCO DE SAN ROMÁN, Lope de Vega y los cómicos toledanos 1935, «Archivo Histórico de Protocolos de Toledo». Valdés se compromete a representarla en Toledo entre el 15 de enero y las Carnestolendas de 1615 y en Sevilla después de Pascua ese mismo año. 
media, desvela la autoría total de Lope, no siendo concluyente ninguno de los argumentos que defienden la colaboración de otro autor, lo que a su vez, deja patente que en su transcripción material ha intervenido también una mano diferente a la del Fénix ${ }^{58}$.

El descubrimiento del manuscrito hizo surgir diferentes hipótesis acerca del autor que había redactado el segundo acto no autógrafo de Lope. Se mantuvo que pertenecía a Fray Alonso Remón, quien habría escrito la comedia en colaboración con Lope ${ }^{59}$.

Pronto surgieron otras voces como Montesinos que señalaron al autor Valdés como copista, tras comparar su firma con la letra del segundo acto ${ }^{60}$.

\section{I.2.C. Estreno y representaciones}

Debió ser estrenada por la compañía de Pedro Valdés en 1615 en Toledo en el Corral de Comedias del Mesón de la Fruta, entre mediados de enero y el comienzo de la Cuaresma.

Pedro Valdés debió reservar el papel de la protagonista madre soltera, a su mujer Jerónima de Burgos ${ }^{61}$.

A pesar de ser una de las actrices más conocidas del Siglo de Oro, Jerónima de Burgos ha pasado a la historia por haber sido una de las amantes de Lope de Vega, el cual dejó en su epistolario y en su obra, las huellas de esa relación personal, que debió de empezar alrededor de 1607; pero el vínculo entre Jerónima de Burgos y Lope de Vega fue también profesional ${ }^{62}$.

58 Res. 110 de la Biblioteca Nacional.

59 VEN SERNA, Observaciones sobre el arte de Alonso Remón dramaturgo Lopista, Actas II. AIH, p. 594. Señala como tema característico del teatro de Alonso Remón la rivalidad amorosa entre miembros de una misma familia; así en el caso de Grandezas de Madrid rivalizan padre e hijo como antecedente de nuestra Comedia.

60 J. F. MONTESINOS, Una nota a la comedia "¿De cuándo acá nos vino?», de Lope de Vega, «Revista de Filología Española», VII. (1920), 178-182. Se ha podido ratificar esta afirmación gracias al manuscrito, conservado en la Biblioteca Nacional, de la comedia de Montalbán La puerta Macarena, «trasladado», como él mismo hace constar al final de la obra, por Valdés y cuya letra es sin duda alguna de la misma mano que la segunda jornada de ¿De cuándo acá nos vino?

61 TIRSO DE MOLINA, Los Cigarrales de Toledo, Madrid 1913, p. 340, donde Tirso de Molina muestra su desagrado un año más tarde en 1615, de que Jerónima corpulenta y adiposa hiciese de don Gil de las Calzas verdes, joven casadera.

${ }^{62}$ LOPE DE VEGA, Cartas, 15, III, 1614 «Gerarda la amiga del buen nombre»y del 25, VII, 1615 donde llena de injurias a «doña Pandorga». Los nombres con los que Lope designa a la actriz en sus cartas reflejan el afecto y el sucesivo distanciamiento 


\section{I.2.D. Laboriosa composición}

El estudio detenido del manuscrito autógrafo - actos primero y tercero- ha permitido comprobar que no son fruto de la repentización sino de un proceso, en el que es posible distinguir la elaboración a la que sometió la idea primera de la comedia ${ }^{63}$.

Y el mismo estudio de los personajes permite adentrarse en el método dramático que Lope iba afianzando progresivamente, intentando el equilibrio entre tradición, inspiración e innovación. El Fénix presenta una nómina en la que no falta ninguno de los personajes arquetípicos, pero aplicando el principio de economía dramática distribuyéndolos en escenas cada vez más imbricadas. La reducción de los personajes conlleva al mismo tiempo la delimitación entre figuras principales y secundarias; el motivo, casi siempre los avatares amorosos de los protagonistas, sustituye a una acumulación de peripecias secundarias, que se van eliminando para evitar la dispersión ${ }^{64}$.

En esta misma línea el espacio también se ve afectado por la simplificación, al mismo tiempo que el ámbito urbano se va haciendo con la exclusiva escénica. ${ }^{65}$.

\section{I.2.E. Transformación y originalidad}

Aprovechando antecedentes literarios cercanos, hace de Doña Bárbara, la madre soltera probablemente el mayor acierto de la comedia, gracias a la rivalidad que establece con su propia hija ${ }^{66}$. También Beltrán, el camarada del protagonista, tiene su antecedente en otras obras ${ }^{67}$.

hasta el odio de Lope respecto a Jerónima y Valdés. A partir de 1610, Lope fue de hecho, el dramaturgo oficial de la compañia de Pedro de Valdés, con obras en las que actuó Jerónima de Burgos, hasta que se produjo finalmente la ruptura con la compañía en 1615.

${ }^{63}$ GAVELA DÉLIA, loc. cit. A pesar del mito de la espontaneidad de sus redacciones, diversos aspectos en la elaboración de esta comedia ponen de manifiesto que el Fénix era además un laborioso artesano que sometía sus creaciones a controles.

${ }^{64}$ En Valencia perfeccionó su fórmula teatral, dando de lado a la unidad de acción, narrando dos historias a la vez en la misma obra, el llamado imbroglio italiano-

${ }_{65}$ GAVELA DÉLIA, loc. cit. Antes de que empiece a funcionar la progresiva conquista de los interiores en consonancia con el auge del protagonismo femenino, se produce una conquista previa del medio urbano.

66 LOPE DE VEGA, La discreta enamorada, Los melindres de Belisa, La malcasada y Quien ama no haga fieros. Estas comedias presentan un tratamiento similar del personaje materno.

${ }^{67}$ LOPE DE VEGA, La noche toledana y El acero de Madrid. 
Esta madre sin esposo, ejerciendo la patria potestad alejada del papel de madre comprensiva, ha tratado de sustituir al padre, adquiriendo la figura femenina en situación que no es lo habitual, un valor decisivo en los asuntos familiares, porque no existe en la casa la autoridad del «paterfamilias».

Por otra parte, no siendo aquí las mujeres las que inician la cuestión, sin embargo en cuanto entran en escena la comedia adquiere ritmo vertiginoso: Una madre soltera disputa el amor a su hija, prendada de los encantos de un apuesto militar y está dispuesta a arrebatarle la presa. Y así adquieren los enredos una dimensión insospechada, en un caos de engaños y peleas entre madre e hija; hasta que como un «deus ex machina» desde Flandes llega el hermano mayor y capitán del soldado, a poner orden y decir la última palabra, impartiendo justicia distributiva teatral ${ }^{68}$.

Resultan significativos los nombres de las dos mujeres, Bárbara la madre soltera, que poniendo patas arriba el orden de su hogar para ser la beneficiada de lo encantos del soldado que le disputa su hija, recurre para ello a la más atroz mentira como arma decisiva para conseguir la victoria ${ }^{69}$. Y Ángela su hija, la joven casadera para la que su madre ha de buscar marido, que descubre el amor romántico, pero que engañada ha de renunciar a él, sufriendo una decepción que en la obra adquiere por un momento tensión dramática, expresada en el único soneto que se declama.

\section{I.2.F. La clasificación}

Los estudiosos han topado con la dificultad de encasillar esta comedia hasta desistir de hacerlo, y referirse más bien a sus singularidades $^{70}$. No obstante un primer acercamiento la consideraba como comedia de capa y espada ${ }^{71}$; pero todavía se ha retrocedido desde el

68 RAFAEL PÉREZ SIERRA, Arte nuevo, nueva comedia, en Introducción a su versión «¿De cuando acá nos vino?» para la Compañía Nacional de Teatro Clásico, Madrid 2009, p. 13.

69 RAFAEL RODRIGUEZ, Costumbres sin costumbrismo, en Introducción a de «¿De cuando acá nos vino?» loc. cit. p. 10.

70 Menéndez y Pelayo creyó respetar la variedad de la obra, incluyéndola entre las "comedias de costumbres», aunque tampoco encaja del todo bien en este apartado, porque lo que ocurre en ella difícilmente puede considerarse habitual.

${ }^{71}$ La expresión de " capa y espada» se ha referido siempre al atavío de calle más que a uniforme de soldado; los militares en este escenario, no desenvainan nunca su espada y si lo hacen no es en serio, se sirven de otros medios; venidos de las guerras de Flandes disfrutan de un periodo paz; las pendencias se dan por lo contrario entre las damas. 
subgénero de capa y espada, hasta la más genérica de «comedia de enredos amorosos» ${ }^{72}$.

La comedia lopesca son fotogramas del Madrid de su tiempo, de su sociedad donde a diario se integran personajes, venidos de cualquier lugar del «imperio», que llegan a la Corte y van abriéndola y transformándola. Son sin duda alguna, tipos de variada galería, como el mayorazgo aragonés, y aun exóticos como el indiano o la esclava morisca, y sobre todo los militares y soldados vueltos de Flandes, capaces de cualquier cosa con tal simplemente de sobrevivir ${ }^{73}$. Pero estos personajes que tratan de vivir y abrirse camino en aquella sociedad, no lo tienen fácil y así les vemos recurrir a trampas y engaños, simulación de enamoramiento, falsificación, suplantación de personalidad, y particularmente en el caso el fingimiento de consanguinidad, como único modo de saltar la barrera que se interpone, con tal de hacerse dueños de la situación.

\section{I.2.G. Ambiente marco. La multiculturalidad}

Apoyándose en referentes reales, Lope se inspira en una circunstancia histórica entre 1612 y 1614, la Tregua de los doce años y la desmovilización de una buena parte de los Tercios en este periodo interbélico de la campaña flamenca, con la consiguiente llegada de soldados desocupados a la capital, para enmarcar su comedia ${ }^{74}$.

Concurren en aquel Madrid elementos que van formando parte de su esencia. Sus damas, galanes y moscones, gentes de Corte, militares, criados y picaros, y sus calles, casas, tabernas, posadas y paseos, con serenatas de músicos contratados para rondar enemoradas que

72 Ciertamente es una "Comedia de enredo amoroso», donde no es fácil sospechar el final porque la suplantación y la ficción amorosa constituyen la trama, consiguiendo el galán pasar por sobrino, y la tía haciéndole hermano de su hija; y fingiendo además el galán estar enamorado de la madre, trayendo equivocada a la hija su verdadero amor correspondido.

${ }^{73}$ EDUARDO VASCO, en Introducción a ¿De cuándo acá nos vino?, Textos de Teatro clásico n. ${ }^{\circ}$ 54, Madrid 2009, p. 9.

${ }^{74}$ MAR ZUBIETA, ¿De cuándo acá nos vino? Cuadernos pedagógicos, 32, Teatro Clásico, p. 21: Esta Tregua hizo ir a Madrid gran número de soldados de los Tercios de Flandes, licenciados por ahorro económico que saturaban plazas y mentideros, entretenidos con los juegos de cartas y todo tipo de rumores y noticias. Eduardo Vasco, director de la Compañía Nacional de Teatro clásico ha dicho definiendo esta comedia, que bien podría titularse «La tentación viene de Flandes». Lo cierto es que cuando se escribe esta obra durante la Tregua con los soldados que se quedan en la ciudad deambulando y sin dinero, había llegado la picaresca. 
convierten a Madrid en símbolo de una España que ha llevado su concepción y su orden al mundo que controla, pero que a su vez agranda su sentido, recogiendo las influencia de todos aquellos territorios periféricos ${ }^{75}$.

Pero es importante subrayar otras circunstancias que afectan profundamente a Lope en su persona durante estos años en que se tiene por escrita esta comedia. Entre las fechas señaladas, en 1612 muere su querido hijo Carlos Felix e ingresa Lope en la Orden Tercera de San Francisco; en 1613 muere su esposa Juana Guardo; y finalmente 1614 es el año de su ordenación sacerdotal.

\section{I.2.H. Las acciones secundarias}

Junto a la acción principal los avatares de la relación amorosa de los protagonistas, se desarrollan dos acciones secundarias paralelas; la de más relieve, implicada en la acción principal, la constituye la presencia de otros dos pretendientes oficiales a la mano de Ángela, los cuales mantienen su propia guerra desde el comienzo hasta el final de la obra, en que la rivalidad supera al intento de los mismos de conquistar a la dama. Toda la acción se muestra implicada en la acción principal, contribuyendo al enredo y a la complicación ${ }^{76}$.

Una segunda acción secundaria la representan los criados de la casa que de algún modo reproducen los celos y las luchas de las señoras. Sus personajes se acercan a los pícaros de cocina y de caballerizas. Está concebida como un entremés incrustado que se entrelaza según se va tejiendo la acción principal ${ }^{77}$.

75 RAFAEL RODRÍGUEZ, loc. cit., p. 10: Ello hace de esta comedia una pieza actual en un mundo que ha de aprender a convivir con las culturas que los inmigrantes aportan y que engrandecen nuestra propia manera de ser.

76 Estos personajes llegan al desenlace con resultado negativo para ellos, pero triunfando cada uno de su oponente. Se ha dicho que fue en Valencia, donde Lope aprendió a desobedecer la unidad de acción, narrando dos historias en vez de una en la misma obra.

77 E. VIVÓ UNDABARRENA, Matrimonio y Derecho en el Teatro del siglo de oro: Cervantes y Caldearon de la Barca, UNED Madrid 2003, p. 99: Cervantes había ensayado el primero este propósito de sustituir el Entremés entre los actos de la Comedia por una acción secundaria de la misma de tipo gracioso, con la doble finalidad de dar ligereza a la obra, al mismo tiempo que se convierte en espejo a nivel burlesco de la acción principal. 


\section{I.3. El impedimento de consanguinidad y su dispensa}

\section{I.3.A. Antecedentes romanos}

Cabe decir de la historia de este impedimento que fue siempre norma vigente en Roma, que entre consanguíneos el matrimonio estaba prohibido, no ya por las leyes escritas sino por las costumbres. Así Ulpiano $^{78}$, y Paulo que lo especifica ${ }^{79}$.

Quien lo contravenía perpetraba incesto y era castigado con la muerte haciéndolo precipitar de la roca Tarpeia o relegado «ad insulam». Pero finalmente el Derecho Romano, tal como se encuentra ya en el Alto Imperio fue bastante tolerante en cuanto a estas prohibiciones del matrimonio tratándose de parentesco colateral ${ }^{80}$. Es de citar al respecto la famosa y efímera excepción del Emperador Claudio, recogida en un texto de Gaio ${ }^{81}$, y relatada en los Anales de Tácito ${ }^{82}$.

La violación del impedimento de parentesco no es siempre una simple transgresión de reglas jurídicas como determinadas prohibiciones en la línea colateral; el incesto en el caso de próximos parientes conlleva una reprobación moral. El Derecho en tal caso no hace otra cosa que traducir el rechazo de las costumbres ${ }^{83}$.

En la línea colateral se extendió el impedimento al cuarto grado, entre primos carnales, prohibición que no duró mucho tiempo en Orien-

78 ULPIANO, Epitome, 5, 6: Entre los parientes en linea colateral, ciertamente que en la antiguedad no se podía contraer matrimonio hasta el cuarto grado; ahora en cambio se puede en tercer grado Si alguno contrajese matrimonio con mujeres con las que la costumbre lo prohibe, se dice que comete incesto.

79 PAULO, D. 23, 2, 39,1 Si alguno contrajese matrimonio con mujeres con las que la costumbre lo prohibe, se dice que comete incesto. Y D. 23, 2, 68: Por Derecho de gentes comete incesto el que se casa con la que está en línea ascendente o descendente; pero al que se hubiera casado con una colateral en grado prohibido, se le castigará levemente si lo hizo abiertamente, y con más rigor si contrajo clandestinamente.

80 JEAN GAUDEMET, Droit Romain et principes canoniques, p. 191. Se puede colegir que el impedimento del matrimonio entre primos hermanos había desaparecido al final de la República y se restablecería en el Bajo Imperio por una Constitución hoy perdida de Teodosio I de la que encontramos alusión en el Código Teodosiano y en San Ambrosio.

${ }^{81}$ GAIO, 1, 61-63 Está permitido casarse con la hija de un hermano, y esto vino a estar en uso por primera vez cuando el divino Claudio quiso casarse con la hija de su hermano; pero en cambio no está permitido casarse con la hija de una hermana.

82 TACITO, Anales, L. 12, 5-7. Fue introducida por el emperador Claudio a través de un Senadoconsulto del año 49, para poder contraer matrimonio con Agripina hija de su hermano Germánico.

83 J. GAUDEMET, El matrimonio en occidente, Madrid 1993, p. 49 : El incesto repugna a la mentalidad romana. 
te, pudiéndose decir que la legislación romana fue en esto vacilante ${ }^{84}$. Finalmente Justiniano en su Código autorizando estos matrimonios de primos representa el último estadio del Derecho Romano ${ }^{85}$.

En cuanto a la dispensa de estas prohibiciones: El emperador puede liberar de las sanciones jurídicas cuando la unión incestuosa no hace otra cosa que quebrantar las prescripciones del Derecho positivo ${ }^{86}$.

\section{I.3.B. En la Iglesia primitiva}

La Ley judía había comenzado por hacer suyo exactamente el punto de vista opuesto, el principio de la endogamia, mandando que todo israelita tomase esposa en su tribu y en su parentela ${ }^{87}$. Más tarde se produce una aplicación restrictiva ${ }^{88}$.

La primitiva normativa canónica no parece que fue mucho más decidida que la legislación romana que fue vacilante: Los Concilios del siglo V se hacen eco del Derecho Romano. Los Concilios occidentales del siglo VI extendieron expresamente la prohibición del matrimonio hasta el sexto grado de consanguinidad en la computación romana, es decir hasta los hijos de primos hermanos. Así el Concilio de Agadé del 506 prohíbe el matrimonio con primos hermanos y primos segundos ${ }^{89}$.

La autoridad de S. Agustín explica la extensión de la prohibición del matrimonio a los primos hermanos ${ }^{90}$. En el Concilio II de Toledo

${ }^{84}$ C. TH. 3, 12, 3: Una interpolación de una Constitución del año 295 prohibió al parecer el matrimonio entre primos hermanos; atenuada en sus sanciones por Arcadio desde el 396, fue suprimida por el mismo unos años más tarde en el 405.

85 C. IUS. 5, 4, 19 Se ha concedido por la bondad de esta ley facultad para que se celebre matrimonio entre primos hermanos, de modo que revocada la autoridad del antiguo derecho, sean considerados legítimos los nacidos de este matrimonio. Se vuelve con ello a la disciplina clásica como consta por la reproducción de la Constitución de Arcadio que autorizaba tales matrimonio en el Código.

${ }^{86}$ Así el emperador Honorio que había vuelto a la prohibición del matrimonio entre primos hermanos subordinará la unión a una dispensa del príncipe.

87 Núm. XXXVI, 7.

${ }^{88}$ Lev. XVIII, 6 s. Prohibe el matrimonio no sólo entre ascendientes y descendientes hasta el infinito sino también entre consanguíneos colaterales próximos, los hermanos, los sobrinos con los tíos y entre los primos.

${ }_{89}$ MANSI, vol. VIII, col. 335, Can. 61: De las uniones incestuosas no reservamos ningún tipo de dispensa, si no es cuando se sana con la separación. Al incesto de ningún modo se le ha de llamar con el nombre de matrimonio.

90 S. AGUSTÍN, La Ciudad de Dios, Lib. XV, 16, M. L. vol. 41, col. 459: Hemos visto por experiencia en los casamientos de primos en nuestro tiempo, que por el grado de parentesco próximo al del hermano, cuántas veces se rechazaba por buena costumbre lo 
del año 527, se estableció para el Reino Visigodo el principio que prohíbe con carácter general el casarse con persona consanguínea; el impedimento se extendía a todos los grados de la consanguinidad tenidos en cuenta en la sucesión ${ }^{91}$.

Por aquel tiempo S. Isidoro, basándose probablemente en fuentes romanas tardías prejustinianeas, reduce el impedimento hasta el sexto $\operatorname{grado}^{92}$. La prohibición matrimonial pasó a la Europa Medieval a través de la «Hispana» de S. Isidoro de Sevilla y del «Liber Iudictiorum»"

Para justificar tal exogamia cabe hablar de un principio superior «la difusión de la caridad», ya que un sistema semejante no se ve sugerido por ninguna de las dos legislaciones en que se inspira principalmente la Iglesia primitiva, ni la ley mosaica ni la romana. Así se expresa S. Agustín: La unión del hombre y de la mujer, por lo que toca al género humano, es un cierto semillero de la ciudad ${ }^{94}$. El matrimonio es concebido como instituido, no sólo para propagar la especie, sino también para desarrollar entre los hombres los sentimientos de amor y caridad, por el parentesco. Ahora bien, no se puede producir plenamente este resultado si no se realiza entre dos personas hasta ese momento extrañas; si se contraía por el contrario entre un hombre y una mujer unidos por el parentesco, éstos ya estaban inducidos a amarse por sus relaciones familiares, y entonces el matrimonio perdía una buena parte de su utilidad social.

Característica de la legislación canónica ha sido la posibilidad de dispensa o relajación de una ley por el superior con justa causa en un caso particular, institución que responde a un ordenamiento cuya ley fundamental es la salus animarum. Esta facultad que la Iglesia ejerce en el matrimonio, es una demostración de su potestad para dispensar de los impedimentos pero solamente de los que ella ha establecido.

que era lícito hacer según las leyes; porque esto, ni la divina lo prohibió, ni la humana lo había vedado. Sin embargo se rehusaba lo que era lícito por lindar con lo ilícito, pues lo que se hacía con la prima, casi parecía que se hacía con la hermana, porque aún entre sí, se llaman hermanos por el parentesco tan cercano.

91 MANSI, vol. II, p. 207: canon 5: Y para precaver saludablemente estas cosas, prohibimos que ninguno de los fieles intente casarse con una parienta de su sangre hasta el limite de parentesco que se reconoce para la sucesión.

92 S. ISIDORO, loc. cit. p. 795: Por tanto la consanguinidad está constituida hasta el sexto grado de generación.

93 R. FERNÁNDEZ ESPINAR, Las prohibiciones de contraer matrimonio entre parientes en la época visigoda, en Revista de la Facultad de Derecho de la Universidad de Madrid, 6, 1962, p. 416.

${ }_{94}$ S. AGUSTÍN, loc. cit. Lib. XV, 16, M. L. vol. 41, col. 459: Existía una razón de caridad, para que los hombres a los que sería de utilidad y concordia honestísima si se vinculaban con los lazos de distintas relaciones, la caridad se extiende en mayor número. 
La Iglesia que en un principio se mostró un tanto remisa (en los primeros siglos del Cristianismo como los impedimentos del matrimonio eran pocos, las dispensas debieron ser muy raras si es que se dieron), luego dispensará cada vez con más frecuencia, atenta siempre a que no se cause perjuicio a los fieles:

S. Gregorio Magno concedió a los Anglos evangelizados por Agustín de Canterbury la facultad para que pudiesen contraer matrimonio en tercero o cuarto grado en línea colateral de consanguinidad ${ }^{95}$.

Este modo de dispensa en sentido amplio (no en caso particular sino general ) se encuentra también en los Concilios Galos de principios del siglo VI: El Concilio Agatense del año 506, concede la convalidación de ciertos matrimonios entre parientes ${ }^{96}$. Lo mismo el Concilio de Epaon, el año 51797, y el Concilio Aurelianense III del año 538 , refiriéndose a quienes se han convertido y también a bautizados que lo ignoraban ${ }^{98}$.

\subsection{El impedimento y su dispensa en el «Corpus Iuris Canonici»}

Aunque no parece que estos impedimentos matrimoniales hayan sido producto de pensada reflexión, el deseo de extender los lazos de amistad y amor entre los cristianos, y el instintivo rechazo de la promiscuidad en que se vivía en los asentamientos rurales de la Alta Edad Media, fue la principal causa que actuó para prohibiciones por razones de parentesco ${ }^{99}$.

95 GREGORIO MAGNO, Epist. XII, 31, Migne L. 77: Lo que escribi a Agustín, obispo de los Anglos que hacía poco se habian convertido a la fe, para que no se volviesen atrás por temor a una disciplina demasiado dura, has de saber que ciertamente lo dije como algo especial; que no se separasen si contrajesen dentro de la propia consanguinidad, esto es hasta la séptima generación. Pero esto lo hemos concedido por ahora, pero no para los tiempos que vengan después.

96 MANSI, vol. VIII, col. 335: Can. 61: Que los que se hallan al presente no se disuelvan.

97 Ibidem, col. 563: Can. 22: Lo que prohibimos en la actualidad, pero sin disolver los matrimonios contraídos antes.

98 Ibidem, vol. IX, 14, can. 10: Por lo que hace a las uniones incestuosas, guárdese lo establecido, pero de modo que aquellos que han accedido hace poco al bautismo o aquellos a los que no ha llegado a su conocimiento por lo reciente de su conversión, y mirando por su fe, no se disuelvan sus matrimonios contraídos de este modo hasta ahora, pero en lo futuro se observe la prohibición de los cánones sobre las uniones incestuosas.

99 ESMEIN GENESTAL, Le Mariage en Droit Canonique, Paris 1929, vol. I, pp. 94 y 373. 
En el Concilio de Roma del año 721 bajo Gregorio II, fue recibida en la Iglesia Romana la prohibición del matrimonio hasta el séptimo grado. Pero el mismo Gregorio II en el 726 mitigaría esta normativa concediendo facultad de dispensar a S. Bonifacio evangelizador de los Anglos ${ }^{100}$. Que los matrimonios en cuarta generación aún cuando estén prohibidos, si se celebran no se deben separar, fue ya norma del Concilio Verberiense y Compediense a mediados del siglo VIII.

Es Ivo de Chartres el que elabora la doctrina sobre la Dispensa, ya vigente en la Iglesia, consagrándole demostrando su necesidad en el funcionamiento de las instituciones y en la vida jurídica de las sociedades. La dispensa no obstante, no ha de estar sujeta al capricho del interesado; depende del superior legítimo y sobre todo del Papa pastor supremo.

No fue hasta la segunda mitad del siglo XI cuando quedó fijada la disciplina sobre los impedimentos de parentesco, hasta constituir un complicado entramado. En el Concilio de Roma de 1059, se mantiene el séptimo grado, pero dicha extensión tenía tales inconvenientes que se imponía al respecto una reforma en la Iglesia.

Con Inocencio III la reforma del Concilio Lateranense IV en el año 1215, el impedimento finaliza en los primos ${ }^{101}$; la prohibición se fija en el cuarto grado porque los hombres de ordinario llegan a saber los constituidos en dicha generación. Los matrimonios celebrados de buena fe en quinto grado y sobre todo en sexto y séptimo grado, habían sido tolerados en la Iglesia aplicando la «disimulatio».

La dispensa de impedimentos de derecho eclesiástico como el legislar sobre el matrimonio estaba reservada al Romano Pontífice,

100 GREGORIO II, Epist. XIV a Bonifacio, c. 1, M. L. vol. 89, col. 524: Como con gente tan bárbara place más usar de la templanza que del rigor, se les ha de conceder que se casen después de la cuarta generación. Y en GRACIANO, Cau. XXXV, q. 8, c. 1: De los grados de consanguinidad de la séptima generación, quienes se encontrasen en ellos, habiendo contraído sin saberlo y habiendo pasado muchos años y tienen hijos y quienes se hallasen en sexto y aun en quinto grado, no se les separe, hasta que con la ayuda de Dios hablemos con ellos. Esto lo digo como misericordia, no como mandato.

101 EXTRA, IV, tit. XIV, c. 8: Con la aprobación del Sagrado Concilio, establecemos por la presente que la prohibición de la unión conyugal no exceda del cuarto grado de consanguinidad, ya que en ulteriores grados no se puede ya sin grave dificultad observar generalmente tal prohibición. Ahora bien restringida la prohibición de la unión conyugal al cuarto grado, queremos que tal prohibición sea definitiva, de tal forma que no obstante las Constituciones que han sido dadas anteriormente sobre el tema por otros o por nosotros mismos, si alguno se atreviese a contraer matrimonio contra esta prohibición, no exista la disculpa de los muchos años de convivencia. 
aun cuando no en todos los lugares estaba sustraída a los Obispos. Inocencio III en 1201 concede dispensa a quienes se habían casado en la infidelidad en tercer grado de consanguinidad, siguiesen casados después del bautismo ${ }^{102}$.

En el siglo XI las dispensas en casos particulares, se refieren a matrimonios ya celebrados ${ }^{103}$; sin embargo la actitud de los Papas en el siglo XII en cuanto a las dispensas de los grados de consanguinidad es rigurosa ${ }^{104}$.

Las legislaciones civiles se preocupan de acomodarse a las prescripciones canónicas, como podemos verlo ya en el Fuero Juzgo ${ }^{105}$. Las Partidas dedican una ley a este propósito bajo el título De los moros e de los judíos que casan segund su ley con sus parientes e sus cuñadas, que no los embargue después que fueron christianos ${ }^{106}$.

102 EXTRA, IV, tit. XIX, c. 9: En tiempos de Urbano III (1185-1187), los Livonienses comenzaron a convertirse a la fe católica abandonando el paganismo. Necesitaban los Livonienses dispensa para poder convivir con las viudas de sus hermanos difuntos con las que se habían casado y para seguir casados en grado de consanguinidad colateral. GRACIANO, Cau. XXXV, q. 8, dictum, y c. 1: Lo expresaba diciendo: A aquellos que se unieron ignorantemente en algún grado de consanguinidad o afinidad se les ha de remitir a la dispensa de la Iglesia, según lo decidió Gregorio II.

103 Nicolás II (1058-1061) permitió a Guillermo duque de Normandía que permaneciese con una pariente en matrimonio celebrado contra la prohibición de León IX. Pascual II (1099-1118) concedió favor semejante a Felipe I de Francia que había tomado por esposa a una consanguínea. El primer ejemplo de dispensa previa dada para contraer legítimamente con una consanguínea, parece que fue a Juan hijo de Enrique II de Inglaterra. También Inocencio III concedió igual gracia a Otón IV de Alemania en 1209.

${ }^{104}$ Queda de manifiesto por la Decretal de Inocencio III en 1199 al arzobispo de Compostela, por la que en lugar de la dispensa repetidas veces solicitada por el Rey Alfonso IX de León para poder convalidar su matrimonio con su sobrina, hija del Rey de Castilla temerariamente atentado, le obligó a disolver tal unión forzándole con la excomunión y el entredicho.

105 FUERO JUZGO, Lib. III, tit. V, ley 1: Nengun omne non ose casar con alguna que es del linaje de su padre o de su madre, o de su avuelo o de su avuela, fasta el VI grado.

106 PARTIDAS, IV, tit. VI, 1. 6: Primos hermanos e los otros parientes que diximos en las leyes antes desta que no deben casar fasta el quarto grado, e si se casaren debe ser desfecho tal casamiento, e los otros embargos que diximos otrosí que vienen en los casamientos por razón de cuñadía, entiendese en los casamientos que son fechos entre los christianos. Más si algunos seyeendo moros o judios casando segun su ley seyendo parientes o cuñados, e después destos se tornasen christianos algunos de aquellos que así fuese casados, non deve ser desfecho el casamiento por esta razon maguer que sean parientes o cuñados hasta el quarto grado. 


\section{I.3.D. La dispensa de consanguinidad y sus taxas en el Concilio de Trento}

Este impedimento todavía conservaba excesiva extensión a pesar de la reducción que se había operado en el Concilio Lateranense IV, de ahí que el Concilio se reafirmase sobre la posibilidad de las dispensas, al tiempo que dejaba en claro la potestad de la Iglesia para establecer impedimentos de parentesco ${ }^{107}$.

El Concilio después de encarecer la prohibición del matrimonio incestuoso, advierte sobre la dispensa de este impedimento, que su uso se ha de hacer con mucha moderación y con causa: Para contraer matrimonio no se den dispensas o se den raramente y ello con causa y gratuitamente. En segundo grado nunca se dispense, ni en tercero a no ser entre grandes Príncipes y por una causa pública ${ }^{108}$.

Con esta singular disposición queda clara además la resistencia de la Iglesia a dar dispensa de matrimonio entre tíos y sobrinos. Sin embargo la Santa Sede, otorgó este género de dispensa y cada vez más, también a personas particulares por justas causas privadas ${ }^{109}$.

Habían sido los Papas de Avignon, especialmente Juan XXII los organizadores de la economía de la Corte Pontificia, estructuarándola de forma que se pudiese sostener con todo su conjunto de Dicasterios.

La prescripción que Trento hacía de la gratuidad de las dispensas en los impedimentos matrimoniales, no afectaba ciertamente a las «taxas» o suma que se exigía para la concesión a los solicitantes ( «oradores»), como estipendio de los oficiales y para las cargas de la cancillería, y que estaban determinadas para cada impedimento. Otro tanto ocurría con las llamadas «expensas», que se refieren a los gastos postales y retribuciones de las «agencias de preces» de Roma si se hacía uso de sus gestiones.

La "composición» o componenda es la suma de dinero que con ocasión de la dispensa, se ha de dar además para que se emplee en obras pias, y que está tasada en los distintos casos. Es claro que su

107 CONCILIO DE TRENTO, Ses. XXIV, can. 3: Si alguno dijere que solo los impedimentos de consanguinidad y afinidad que se encuentran en el Levítico pueden impedir contraer matrimonio o dirimir el contraído, y que no puede la Iglesia dispensar de algunos de ellos, o establecer que sean más los que lo impiden y dirimen, sea anatema.

108 CONCILIO DE TRENTO, Ses. XXIV, De Reformatione, cap. 5: Si realizadas las solemnidades requeridas, se enteran luego los contrayentes que existe algún impedimento del que se tuvo ignorancia cosa que se puede probar, entonces más fácil y gratuitamente se le pueda dispensar.

109 WERNZ VIDAL, Ius Matrimoniale, Roma 1940, p. 453. 
justificación es distinta de las razones para las taxas y expensas, que tiene la razón de una multa o penitencia impuesta por el quebranto de la ley, como limosna a favor de obras pías, con el fin de no hacer demasiado fáciles y aun frívolas las peticiones de dispensa ${ }^{110}$.

\section{I.3.E. Supuestos y realidades en el caso}

Obsérvese que la consanguinidad base de todo el enredo de la comedia se formula por partida doble. Si el soldado de Flandes simula ser hijo bastardo del Capitán, hermano de una de las protagonistas, en consanguinidad colateral, ésta utiliza similar engaño pero el indispensable de la línea recta para hacer imposible el matrimonio del galán con su hija. Lope ha planteado el engaño de la consanguinidad con dos situaciones bien distintas: la primera en el cuarto grado, dispensable y bastante corriente y en el de tercero también dispensable aunque menos frecuente; y la segunda inventada por la protagonista enamorada, que haría imposible el matrimonio por consanguinidad no dispensable en segundo grado de línea colateral y en línea recta.

Pero advirtamos que la cuestión de la consanguinidad sólo ha sido una estratagema, lejos de toda realidad, como un modo para ser acogidos los dos soldados en la casa de las Fajardo. Es decir que toda la comedia con sus enredos se mantiene en una falacia sin base, que el espectador conoce desde el primer momento, aunque no así las protagonistas engañadas, ni los rivales amorosos; solo malicia el engaño el criado en su papel de pícaro acostumbrado. Esto sólo, nos haría sospechar el sentido paródico de la «dispensa de consanguinidad» en que se mantiene el desarollo de los distintos avatares de la comedia, con el señuelo de una solución sin consistencia.

Pero ello es sólo el presupuesto de la insistente detenida referencia que Lope hace a la concesión de las dispensas en su tiempo, que forzosamente no tiene otro significado que el de ser un retrato de una costumbre matrimonial alejada sustancialmente de los propósitos de vuelta a la praxis de la Iglesia primitiva propugnada por el Concilio, a saber, que tales dispensas no fuesen frecuentes y fuesen gratuitas, y que la de tercer grado solo se concediese en una causa de bien público. Ni uno solo de los tres condicionamientos, sino todo lo contrario se aprecia en el texto de la comedia.

110 WERNZ VIDAL, loc. cit. p. 564, n. 123. 
Advirtamos que Lope solo constata esta relajada costumbre del matrimonio entre consanguíneos en contra de los deseos reformadores del Concilio de Trento y tan distante de la doctrina de San Agustin, para quien el matrimonio «seminarium reipublicae» era un modo de extender las relaciones afectivas entre los hombres, con la actitud contraria que facilitaba el trato amoroso dentro de los muros domésticos, hasta hacerse proverbial ${ }^{111}$. Ninguna crítica expresa se formula a la concesión de dispensas matrimoniales, si se exceptúa tal vez a la del tercer grado de consanguinidad, a la que con razón jugando con el nombre de la madre protagonista se le llama «bárbara». Y no resulta coherente otra actitud dado el estado anímico en que Lope vive en estos años de infortunio y acercamiento a la Iglesia en que escribe esta comedia. Lo que sí hace ciertamente, es fustigar esta corruptela, pues de otra forma no se explica el que nada menos que dieciséis veces se haga mención en los dos últimos actos de la Comedia de la «dispensa matrimonial» de consanguinidad.

Es finalmente en la última escena que resuelve el enredo, cuando quedan en claro los propósitos paródicos de la comedia que ha intentado llegar al amor sirviéndose del atajo que proporciona el trato asiduo de la consanguinidad. El Capitán que como clave del engaño nos devuelve a la realidad, operando libremente al margen de cualquier dispensa que se ha mostrado innecesaria por inexistencia del supuesto proporciona marido a las dos damas, a la hija con el alférez, porque entre ellos se da el amor verdadero sin necesidad de otros recursos, y a su hermana con el otro soldado que ha hospedado en su casa como matrimonio más de circunstancias. Téngase en cuenta que Ángela difícilmente hubiese podido presentar una causa canónica para la concesión de «dispensa de consanguinidad», pues ni su edad "florens», ni la escasez de jóvenes en su ciudad se dan en el caso, y sobre todo cuenta con pretendientes jóvenes adecuados que Lope ha tenido cuidado en diseñar, a saber un noble mayorazgo y un rico indiano que se la disputan.

111 Don Esteban el noble rival amoroso cuando se le dice que el nuevo personaje que ha irrumpido en la familia de Ángela es un primo suyo, se expresa con un dicho que había alcanzado el rango de refrán «miel sobre hojuelas se llama, sobre parentesco amor». 


\section{EN LA ESCENA}

\section{II.1. Acto primero: «Dramatis personae»}

El primer acto se dedica a la presentación de los principales personajes y a la ambientación que se califica de «muy exterior».

\section{II.1.A. El Alférez Leonardo se licencia del Tercio en Flandes}

La escena se abre en Flandes durante la Tregua de los doce años, donde el autor presenta al protagonista al que acompaña un camarada en su despedida del Tercio, licenciado para marchar a Madrid $^{112}$

Junto a los escritos de recomendación de los Gobernadores, el archiduque Alberto de Austria y su esposa la Infanta Isabel Clara Eugenia que lleva para el Rey, el capitán le entrega también una carta para una hermana que tiene en Madrid, que es rica y puede serle útil en caso de necesidad, carta clave de todos los enredos de la Comedia ${ }^{113}$.

\section{II.1.B. Ángela y sus pretendientes rivales}

Ya la segunda escena nos sitúa en Madrid de aquellos tiempos colocándonos en la calle donde rondan dos pretendientes de una doncella de calidad ${ }^{114}$. Don Esteban joven mayorazgo Aragonés, al que otro noble maduro y madrileño don Alonso le alecciona dándonos con ello noticia de Ángela y de Bárbara las protagonistas:

Doña Ángela no pierde en nacimiento / aunque no es legítima; pues un conde / sospecho que alemán, dando palabra / de casamiento y cédula a su madre, / la tuvo sin cumplirla, o porque fuese / su gusto así o por no le dar su Majestad licencia. / Volviose el Conde, aunque dejó a su hija / hermosa cantidad para su dote.

112 Son significativas las palabras que se cruzan entre el capitán Fajardo y el alférez, que nos sugieren de algún modo el final de la comedia:-Como a hijo os he querido. / ...Y yo por padre, Señor.

113 El Capitan le hace entrega de una cadena de oro, explicando que en Madrid, van despacio las cosas / y se gasta mucho allí, con lo que se inician las referencias a los parásitos y posadas de Madrid que, sepulturas son de ignorantes pretendientes.

114 Adviértese la ruptura nada más iniciarse la comedia con la tradicional unidad de lugar, situándose sin otra transición a muchos kilómetros de distancia. 
El galán deseoso de encontrar esposa, no pone por ello reparos ${ }^{115}$; pero sin duda que la mejor excusa es la dote de la que le han informado.

La comedia nos lleva luego al Soto del Manzanares lugar de esparcimiento, típico en este género de comedias, donde otro pretendiente don Octavio, un indiano que ha hecho fortuna en las Américas espera a la dama, para darle una serenata ${ }^{116}$. Octavio con sus músicos corteja a la bella cuya madre le hace sentar junto a ellas ${ }^{117}$.

Y cómo era de esperar, el otro noble pretendiente a quien la joven parece preferir, se hace presente, lo que provoca la marcha de Octavio con sus músicos, no sin antes sobornar al criado de las damas; lo mismo hace don Esteban, con lo que se da por concluida la merienda campestre.

\section{II.1.C. El alferez Leonardo y el soldado Beltran en Madrid}

La escena final de este acto nos coloca a la entrada de la calle Mayor, en las gradas de la iglesia de san Felipe, lugar clásico en el que Lope se detiene espaciosamente dándonos una estampa castiza de aquellos tiempos ${ }^{118}$. Los soldados licenciados de los Tercios que pululan por la Corte en busca de una recompensa o de un empleo, tienen en aquel pórtico punto de reunión y de información, lo que les permite al mismo tiempo otear y seguir a la bellas que salen de Misa.

Para el alférez Leonardo y el soldado Beltrán esta competencia de soldados es el primer contratiempo que encuentran en Madrid, porque también ellos vienen a pretender en la Corte. Frecuentando este lugar pronto consiguen quedarse sin blanca entreteniéndose con el juego, y con mejor fortuna la vista de Ángela que con su madre sale

115 Pues siendo tan principal hombre su padre / y engañando con cédula a su madre / bien queda el nacimiento disculpado Referencia jurídica a una unión marital que no pudo pasar a convertirse en matrimonio, que alude como posible causa la negativa del Rey para que el Conde contrajese con mujer no perteneciente a la nobleza, lo cual suavizaba socialmente la mala imagen de madre soltera y de hija bastarda.

116 Creo que vendrán / a pasar por el sombrio / de las orillas del rio. / Ya los músicos espero / para sin hablar decir / lo que pienso y lo que espero. Don Octavio indiano sin ninguna pretensión de nobleza, ha vuelto para casarse con una mujer conveniente, y volverse a seguir haciendo dinero.

117 Escena que parece reproducir la pintura de Jan Van Kessel, «Vista de la carrera de S. Jerónimo y el paseo del Prado con cortejo de carrozas». (Museo Thyssen Bornesmiza)

118 VÉLEZ DE GUEVARA, El Diablo cojuelo: es el «mentidero de soldados de donde salen las nuevas primero que los sucesos». 
¿DE CUÁNDO ACÁ NOS VINO? LOPE DE VEGA Y EL TABÚ DEL INCESTO

de la iglesia encandilando al alférez; pero como han dado las doce, Beltrán que prefiere las criadas por más fáciles, obliga a posponer el seguimiento de la dama hasta después de haber comido.

\section{II.1.D. La visita de los pretendientes oficiales}

Tras la interrumpida representación campestre y la fugaz visión saliendo de la Iglesia, se nos muestra detenidamente a la madre a la que se presenta desviviéndose por su hija, disponiéndola a recibir la visita anunciada de Octavio uno de sus pretendientes ${ }^{119}$.

Y como la visita es interrumpida por el otro pretendiente, don Esteban presentado por su valedor don Alonso el aristócrata, se produce el enfrentamiento, marchando de nuevo amenazándose ${ }^{120}$.

\section{II.1.E. El alférez, Beltrán y la carta del Capitán}

El juego ha dejado sin blanca al alférez, y pensando qué ha de hacer / pretendiente, sin dinero, se acuerda de la carta que le dio el Capitán. A Beltrán su pícaro consejero, se le ocurre falsificarla, haciéndole decir en la presentación que la carta hace de Leonardo, que es hijo del Capitán Fajardo, hermano de doña Bárbara, al que tuvo en su mocedad de una dama flamenca; en consecuencia que es su sobrino, al que sin duda querrá hospedar en su casa, porque a un sobrino de tu talle / no te han de echar a la calle.

La madre y la hija se lamentan del fracaso de los pretendientes que han estado a punto de desafiarse. La hija se queja de la clausura y vigilancia en que la tiene su madre; la madre mientras reconoce que Ángela es la misma inocencia le replica exculpándose, porque casa sin hombre y sin dueño / de esta suerte se gobierna.

\section{II.2. Acto segundo: La carta que abre puertas y corazones}

De lleno en el argumento en que un galán apasionado enamora a una joven que en este caso, no es lo de siempre, porque en la comedia

\footnotetext{
119 Después de aconsejarle compostura, honestidad y mucho aviso, la instruye: Que no has de hablar, ni callar advierte /que hablando serás tenida / por loca, y necia callando.

120 Una vez sólas, Ángela preguntada por su madre a cuál de los dos se inclina responde: - A ninguno/ pero si alguno deseo, / no de los dos, de los tres / es a don Alonso. I - Si él no te pretende. I-Por eso.
} 
del genial Lope, ese amor también prende inesperadamente en la madre soltera de la muchacha, que ha quedado trastornada por los encantos del apuesto soldado y está dispuesta a arrebatarle la presa a su propia hija. Y ahí comienzan, los enredos, los engaños, las peleas entre madre e hija ${ }^{121}$.

\section{II.2.A. Huéspedes de doña Bárbara}

$\mathrm{Al}$ anuncio de la visita de los dos militares, la madre ordena a su hija que se vaya, quejándose ésta de que la oculte de los jóvenes. De inmediato, éstos se percatan de que Bárbara es la que acompañaba a la bella en san Felipe. Han venido a entregarle la carta que va a remediar su situación. La destinataria lee estupefacta:

El que ésta lleva / es Leonardo mi hijo / y de una dama flamenca / de lo mejor.

En su sorpresa y emoción, Bárbara llama a su hija para que abrace a su primo Leonardo, que no puede menos de exclamar ¿Prima tan bella / tenía yo en España?

El primo fingido relatando su historia explica: -No quiso que se supiera / que era su hijo, hasta hacerla / a madama Flor, mi madre /su mujer $^{122}$.

El alférez fingiéndose comedido pide licencia para marcharse, pues tienen que buscar posada. Bárbara, como habían previsto, sale al paso rogándoles se hospeden en su casa ${ }^{123}$.

\section{II.2.B. Pretendientes que se informan en la calle}

Octavio el indiano que está rondando la casa, informado de la presencia del primo, se lamenta: Si es su primo / y en su misma casa está, / los celos hánseme entrado / con la ventaja que tiene. Pero su avispado criado le sugiere el remedio de que se haga amigo suyo.

121 El protagonismo femenino rompe el esquema de lo que es habitual: la madre mujer protectora de su hija se convierte en su rival.Todo ello confiere un aire de vodevil a esta comedia llena de vida por su dinamismo y ritmo.

122 Bárbara, en aparte: -iQue libre que lo confiesa! / ¡Cómo debe de saber / que mi hija se asemeja / en todo a su condición.

123 A la razón de que no se puede separar de su camarada que ha venido solo para acompañarle, ella replica que la casa es grande y hay sitio para todos. La satisfación de los soldados por el inmediato éxito del engaño se expresa en un aparte: Que ya tienes en Madrid / mientras el Rey te provea / cuanto puedes desear. 
Como era de esperar en la ronda confluye don Esteban, informado por don Alonso de la aparición del militar:

- Celos en el alma siento.

-Tiene el soldado buen talle / pero siendo primo suyo, / no es justo que los tengáis.

- Miel sobre hojuelas se llama / sobre parentesco amor.

Cuando advierten que el indiano rival ha marchado, continúa el diálogo ${ }^{124}$,

- ¿Y el primo?/ Pues ¿vos no me asegurais / que de él los celos no sienta?

—Si hay dispensación a cuenta / no es malo que los tengais ${ }^{125}$.

\section{II.2.C. Confesión del alférez.}

Cuando a solas Beltrán le pondera su suerte pues, tiene tal mesa y cama y tal dama, el alférez le replica quejoso de que, ya todo perdiendo se va; su aclaración sorprende a Beltrán el muñidor del engaño:

- ¿No me deciais ayer / que doña Ángela te adora?

—Lo mismo me dice hora, / pero, ¿qué tengo de hacer / si su madre da en lo mismo?

El diálogo que sigue a continuación, no sólo expresa con habilidad el nudo de la trama, sino que al mismo tiempo es una acabada observación psicológica del proceso del amor facilitado por el parentesco:

-Beltrán, parentesco y trato / ¿qué han de engendrar?

-Voluntad

-Y si un deudo y una deuda / comen junto muchos días / ¿qué ha de resultar?

-Amor

-Y si dan en regalarse / y sobra la libertad / ¿qué pueden hacer?

- Gozarse.

124 Una observación de don Alonso que por su edad resulta más experimentado: -Ángela me ha parecido / que ya se inclina a don Octavio / ya os mira a vos, ya a mi. / - ¿A vos? /

- Para dar a entender / que a ninguno tiene amor.

125 Adviertase la referencia a la «dispensa de parentesco», que suena ya como un adelanto para expectadores. 
Luego entre el alférez y su pícaro consejero se evalúa la situación inesperada y equívoca en que se ve Leonardo:

—¿Qué haré de Bárbara amado?

-Amarla

-Aunque quiera no podré./ ¿Y si se quiere casar?

-Eso es lo mejor; haciendo / que traigan dispensación/ pues entre tanto, podeis / hacer que de Ángela estéis/ en segura posesión ${ }^{126}$.

\section{II.2.D. Enamoramiento de Doña Bárbara y celos de Ángela}

Bárbara en un soliloquio no solo descubre su amor por el alférez que califica de desatino ${ }^{127}$, traza la estrategia para conseguirlo, casando primero a su hija ${ }^{128}$.

El alférez al hablar con Ángela la encuentra celosa de su madre que los espía:

- ¿Celos Ángela de qué?

-De que mi madre te mira.

- ¿Por qué no me ha de querer / siendo su sangre y sobrino?.

II.2.E. Ángela sorprende a su madre declarándose al alférez.

Cuando Bárbara suspicaz y celosa, manda a su hija que se vaya, pues ella ha de tratar con su sobrino de los pretendientes de Ángela, ésta también celosa porque algo sospecha, los espía sin lograr escuchar la declaración de amor de su madre:

-Ya que han querido los Cielos / que aquí de Flandes vinieses / que aunque yo sea tu tía / bien nos podemos casar.

\footnotetext{
126 Observese que en el caso la referencia a la dispensa y su obtención supone que va a tener un tiempo que le permita gozar de su prometida.

127 MAR ZUBIETA, loc. cit. p. 32. Doña Bárbara que se enamoró muy jóven, quedando frustrada ha reprimido su deseo de amar, siendo madre entregada; pero cuando las circunstancias le ponen delante un apuesto familiar al que puede acercarse, vuelve a enamorarse de nuevo.

128 Bárbara en aparte: Desde la ausencia del Conde / no he tenido pensamiento / ni aun un primer movimiento / desto que a amor corresponde / Pero yo, ¿qué me fatigo? I Es mejor darme prisa / a casar a Ángela, y luego / declarar este amor ciego.
} 
-Sólo me aflije el temor / de lo que puede sentir / el Capitán mi señor.

-Pues para eso, tratar / estas cosas con secreto / que casados una vez, / tómelo como quisiere./ Por una dispensación / quiero al momento enviar. / Gástese toda mi hacienda ${ }^{129}$.

Ángela que oculta ha visto la actitud cariñosa de ambos, irrumpe e interrumpe la conversación de Bárbara y Leonardo. Reprocha a su madre su actuación amorosa con el alférez, rechazando su explicación de estar aconsejándose con él sobre lo que a ella importa.

La madre reacciona con una actitud absolutamente autoritaria negándose a consultar a su hija ${ }^{130}$. Ángela con el mismo lenguaje y actitud que ha empleado su madre, irrumpe defendiendo su derecho al amor.

-Primo, hazte allá, que quiero / tratar tus cosas también / con mi señora, y no es bien / que estés aquí131.

\section{II.2.F. Hija que se revela y enfrenta a la madre}

Una vez que el alférez las ha dejado solas, se extrema el enfretamiento. Barbara hace saber que es la dueña, que puede decir y hacer en su casa y familia, y que la hija no ha de entrometerse en sus cosas. Ángela por su parte responde que ha visto y oído que ama a Leonardo ${ }^{132}$.

A Bárbara que insiste en que Ángela se ha de casar con uno de los dos que la pretenden, ésta ha manifiestado su oposición, continuando un duro y movido diálogo.

-Casarte quiero / que yo no te he de guardar. / Pues has de saber / que no quiero estar más tiempo sin casarme./

129 El autor que sabe muy bien que en el caso se trata de la dispensa más dificultosa de obtener a saber la de tercer grado en línea colateral, por lo que tiene expensas más gravosas, hace decir a Barbara que para ello tiene el propósito si es necesario emplear su hacienda.

130 - Ves que en tus cosas estamos / y andas necia alrededor / más que una mosca importuna. / ¿No se ha de tratar ninguna / sin tu consejo y favor? / Pues bien se ha de hacer sin él.

131 MAR ZUBIETA, loc. cit. p. 35. Ángela ha evolucionado bruscamente de adolescente a mujer; el ángel que es al principio de la obra, ha descendido a tierra encajando los golpes de la realidad.

${ }^{132}$ La madre replica que lo que trata con su sobrino es con cual de los dos pretendientes ha de casarla, cosa que ella rechaza: Que me aconseje entre los dos / que te pretenden./

- Pues advierte / que a cualquiera de los dos aborrezco. 
- ¿Quién te lo quita?/

-No quiero / que digan que yo me caso / y que por casar te dejo.

\section{II.2.G. Cruel engaño de Bárbara y desolación de Ángela}

Se llega al momento álgido que lleva a la madre en su egoismo al más cruel y retorcido de los engaños, al echar mano al tabú del incesto.

- Te has de casar primero.

-Pues madre me has de casar con mi primo.

-No puedes.

- ¿Por qué no?

- iAy Dios! Si me has de obligar / a que te diga un secreto

-El secreto es, que como yo le quiero, / le quieres para casarte.

-Escucha y verás presto / que es imposible./ Este Leonardo, es tu hermano.

- ¿ Mi hermano?

- Sabe que el piensa que es mi sobrino / porque no sabe el secreto.

—¿Qué tus hijos los dos somos?

-Mi honor hija te encomiendo. / No sepa aquesto tu hermano.

Estamos ante una verdadera situación dramática en lo que no deja de ser una comedia. La hija que a pesar de todo, frente a la bárbara madre, sigue siendo ángel, se apresta a consumar su sacrificio:

-Y para que ya los dos /más cuidados no te demos / te suplico que me cases / con don Esteban.

- No deseo otra cosa.

Y Lope poeta de los sonetos, el único que escribe en esta obra lo reserva para este momento dramático en que Ángela engañada se ve hundida y sacrificada; pone a su cargo una de las dramáticas y bellas escenas, de quien no tiene más remedio que aceptar lo imposible de ese amor:

Mal empleados pensamientos míos

aun antes de nacidos acabados,

pero en buena sazón desengañados.

Si de ti las venas tengo llenas

Leonardo, sal que eres sangre propia

para que cese el fuego de mis penas. 


\section{II.2.H. Perplejidad del alférez.}

Leonardo en un encuentro fugaz a solas con Ángela, acusa su frialdad, que le da a conocer que su madre la ha prometido a don Esteban. Leonardo imaginando de inmediato lo ocurrido lo explicará a su camarada:

-Ésta ha sabido el intento / del fingido casamiento / y perdida la esperanza / se casa con don Esteban. ¿Qué haré Beltrán?

- Proseguir en casarte y en fingir / mientras el nido te ceban.

Leonardo aconsejado de Beltrán va a seguir fingiendo. Mientras doña Bárbara trata con don Esteban del casamiento ${ }^{133}$.

\section{II.2.I. Ángela descubre el cruel embuste de su madre}

Doña Bárbara que recriminando a su hija el atrevimiento con que la trata, tiene con ella el más violento altercado en que se ponen las cosas al descubierto: Hace saber a Ángela que ha concertado con don Esteban su casamiento y que ha preparado escrito de un notario para la aceptación de ella; y que Bárbara prepara también con tiempo su propia boda.

Pero la hija ha podido entender el engaño urdido por su madre, al saber que ésta va a solicitar la dispensa de parentesco, cosa que sería absolutamente imposible de tratarse de consanguinidad en línea recta ${ }^{134}$. Se hace mención de la dispensa y de sus costosas expensas.

Bárbara reconoce ante su hija su estratégico engaño ${ }^{135}$. La oposición de la hija para impedir el matrimonio de la madre, se expresa con el tecnicismo de un experto en Derecho canónico:

-No importa en el casamiento / el traer dispensación; / que sabré poner un impedimento.

133 Octavio tratando de congraciarse con Leonardo siguiendo el consejo de su criado, le envía con éste el regalo de un caballo y una misiva pidiéndole que apoye su pretensión de casamiento con su prima.

134 - Cuando mil ducados cuentas / y dispensación intentas / para casar con Leonardo. ¿ ¿Y quieres darme a entender que es tu hijo?

135 -Quise hacer / de mi amor este resguardo / hasta casarte, no más. I Y ya la cédula firmada / no puedes volverte atrás.

-Tu me has hecho esta traición / i Y dices que amor me tienes!

- Te vi inclinda a tu primo, / y yo le adoro, ¿qué quieres? / Así somos las mujeres. 
- ¿Qué impedimento?

-Decir que es tu hijo / y que lo sé de tu boca ${ }^{136}$.

\section{II.2.J. "Y ¿de cuándo acá nos vino?»}

Va a terminar el Acto central, con una escena que explica el título de la Comedia según se expresan todos los personajes.

Los dos soldados interrumpen la pelea de las dos mujeres; preguntando la causa de la misma; Bárbara da cuenta a Leonardo del atrevimiento de Ángela que dice que eres mi hijo / y que eres hermano suyo. / Ha querido con esta invención / impedirnos el tratado casamiento / después que la necia ha visto / que se ha de partir la hacienda ${ }^{137}$.

Leonardo finge seguir el propósito de Bárbara, posesionándose de su nuevo papel:

-Que esta casa tiene dueño / y esta señora marido./ Y ya no me tengais por primo. / Vuestro padre soy / desde que con vuestra madre estoy casado $^{138}$.

Y doña Bárbara, a pesar de que también a ella le ordena ir atender a don Esteban y al notario que han venido, la cual como dice temerle ya como marido, es la única que no hay miedo que diga «que de cuándo acá nos vino» ${ }^{139}$.

Todos marchan y quedan a solas Leonardo y Ángela, que se desata en denuestos contra el alférez llamándolo traidor, enemigo, y ahora padrastro. Éste le confiesa que todo lo han causado sus celos de ver que tan de improviso se casaba con don Esteban; que ella explica que lo hacía por no poderse casar con él, que era su hermano como le

136 Adviértase la referencia a la denuncia de impedimentos que no permite la celebración de un matrimonio. Ángela va a oponer un impedimento de derecho natural, en el grado más próximo en la línea recta, cuya existencia atestiguará haberla oido a la causante. Por lo que concluye: ;Bárbara madre a quien hoy / viene tu nombre tan justo! / No vas a lograr tu gusto.

137 Bárbara enlaza un embuste más, el del egoismo de Ángela para que no se parta su herencia, para hacer creer que su hija no dice verdad sobre la maternidad que le atribuye.

138 Y cuando Ángela asegura que impedirá el casamiento presentando a sus criados allí presentes como testigos, el nuevo amo les ordena a éstos marchar a sus trabajos de la cocina y la caballeriza mostrando ellos su admiración: «¿Y de cuando acá nos vino?»

139 Según Lope el criado, hasta el papagayo dice ya por las mañanas «que de cuándo acá nos vino». 
había dicho su madre. Y concluye con la reconciliación de los dos enamorados en que una vez más se menciona la dispensa ${ }^{140}$.

\section{II.3. Acto tercero: Desenredando el desenlace}

\section{II.3.A. Los pretendientes oficiales frente al matrimonio de Ángela}

La confusión aumenta. Don Esteban y Octavio bien informados de lo que pasa se han conchabado para estorbar la actuación del alférez, a quien ven como su verdadero rival, hecho dueño de la situación y de la casa. Por el criado saben que doña Bárbara le adora / y la dispensación están esperando ahora;/ pero parece también / que doña Ángela / debe quererle también ${ }^{141}$.

El proyectado matrimonio con don Esteban, se tuerce en favor de Octavio por estrategia de Leonardo con vistas a demorar la boda de Ángela ${ }^{142}$.

Reflejando una sociedad en que no cuenta la voluntad de elección de las hijas para el matrimonio, Ángela entra en escena para saber que han decidido su madre y su sobrino asesor:

-En fin ¿qué se concertó?

-Que no será tu marido don Esteban sino Octavio.

- ¿Y tu Leonardo qué dices?

(En un aparte de Leonardo a Ángela)

-Que es de risa / porque la dispensación / que ha de venir para ella / se ha pedido para $t i^{143}$.

\footnotetext{
140 - ¿Te casarás con mi madre?/

— ¿No ves que todo lo finjo hasta llegar a ser tuyo?/ -Pues, ¿Cómo han ido por esta dispensación?!

-No hayas miedo aunque hayan ido, / que vaya el dinero a Roma, / que irán los quinientos hoy./

-Ya no digo / primo que de cuando acá, / sino que del cielo vino.

141 Una vez más y ésta en boca de un criado se menciona la dispensa que se espera, al mismo tiempo que da cuenta de las peleas por celos entre madre e hija, y el duro trato que por lo mismo le da la madre.

142 Aunque a Bárbara no le parece que después de escrito y firmado se haya de deshacer el compromiso, Leonardo la convence, para que la case con Octavio el indiano, porque así la llevará lejos y los dejará en paz.

143 Adviértase la repetidísima referencia a la dispensa, como una ironía ya que ésta ni siquiera podrá tener lugar.
} 


\section{II.3.B. Desconcierto por la llegada del Capitán}

Cruza la escena Beltrán muy alterado porque ha visto muy cerca de la casa al Capitán Fajardo que inesperadamente ha llegado a España. Los dos soldados marchan a toda prisa dando a doña Barbara la excusa de ir a saber de la dispensa antes de un viaje que han de hacer ${ }^{144}$.

Cuando la criada anuncia una buena noticia, Bárbara obsesionada y ansiosa pregunta: ¿Vino la dispensación? Pero la alegre nueva es la aparición del Capitán Fajardo que llevaba muchos años ausente. Éste al entrar y al ver a Ángela, exclama:

-iQué hermosa y bella, que gentil presencia! / Si fuera mozo yo / fueran dispensación estas razones ${ }^{145}$.

Ángela ha respondido haciendo significativamente suyo el tema. -No faltan por acá dispensaciones,

Y el Capitán vuelve a sus cumplidos con nueva mención de la dispensa para el matrimonio con su sobrina ${ }^{146}$.

Por más que no deje de ser una galantería, la posibilidad de matrimonio en este caso de tío y sobrina, nos está significando lo corriente que se había hecho tal matrimonio entre tales consanguíneos y su dispensa ${ }^{147}$.

\section{II.3.C. El hijo fingido del Capitán Fajardo}

A las primeras palabras que entre sí cruzan los hermanos, se descubre el engaño del alférez, pues cuando Bárbara le habla de Leonardo, el Capitán Fajardo niega naturalmente haber tenido un hijo en Flandes:

-Yo por vuestra carta, he recibido / en mi casa al alférez. Leonardo I como a mi sobrino e hijo vuestro.

144 _Mi señora a saber llego / de nuestra dispensación / y a prevenir un viaje / que a Illescas tengo de hacer.

${ }^{145}$ Y una vez más y en un breve espacio vuelve otras dos veces el tema de las dispensas matrimoniales, primero en boca del Capitán, admirado de su sobrina a quien dejó muy pequeña.

146 -Vuestro galán seré de pensamiento; / que como os dije, si otra edad tuviera, / nuestra dispensación no se excusara.

147 Curiosamente este caso donde realmente hay consanguinidad se plantea sólo como hipotético, frente a los otros que presentados como reales eran sobre una consanguinidad fingida e inexistente. Significativamente el tema queda subrayado a continuación con un aparte, extraña referencia de doña Bárbara: Tanta dispensación mucho me altera, / pero, a no lo saber, no lo tratara. 
-Yo tuve a Leonardo en Flandes por alférez / y cuando vino, le di una mía para vos / diciendo que era mi alférez, pero no mi hijo.

Informado el Capitán de que Leonardo está compañado de Beltrán cuyas trapacerías conoce, y que suelen acudir a las gradas de san Felipe, sale enfurecido en busca del alférez.

\section{II.3.D. El Capitán y el Alférez.}

Cuando el Capitán Fajardo da con los dos soldados, a los que incita a que pongan mano en sus espadas espetándoles su indignación por haber falseado la carta para su hermana, Leonardo tiene la entereza de pedirle le escuche; en un largo parlamento el Capitán le deja contar sus avatares en Madrid, donde pronto se quedó sin dinero y en la calle.

El alférez en su descargo consigue convencer a su Capitán, que no ha sido ofensa fingirse su hijo, porque ha dado al Capitán el honor de su madre. Y le suplica, que hasta que el Rey me provea / me dejes llamar tu hijo.

\section{II.3.E. Todos en la casa de doña Barbara}

Todavía Ángela hace burla de su madre recordándole: ¿Si habrá de Roma venido / aquella dispensación? La referencia es ahora a la inutilidad de la misma.

Las damas alborotadas cuando ven entrar a los dos soldados se deshacen en denuestros, despachándolos de la casa. Ante la sorpresa de los mismos, ellas les explican como ha llegado el Capitán Fajardo y ha negado que Leandro sea su hijo; ellos simulan extrañeza, asegurando lo contrario, insinuando que por alguna razón política el Capitán quiere ocultarlo. Cuando éste llega a la casa explica el por qué de haberlo negado, diciendo que al saber que te casabas / con una vil mujer, y a eso de Flandes / vine furioso.

\section{II.3.F. El Capitán Fajardo pone orden}

Como hermano mayor de doña Bárbara soltera, va a hacer las funciones del hombre que no hay en aquella casa ${ }^{148}$ : Se ha de empezar por casar a Ángela que está en el dilema de escoger entre dos pretendientes, el indiano rico y el noble aragonés.

148 No me pienso volver sin que en sosiego / quede hermana querida vuestra casa. 
Cuando el Capitán convoca a los candidatos, Ángela a solas con él, tiene un largo parlamento. En el relato de su enamoramiento no podía faltar la alusión a la consanguinidad: Amor a amar me previno, / que ser la sangre tercera / disculpa mi desatino ${ }^{149}$.

Luego cuenta el asalto de su madre perdidamente enamorada de Leonardo ${ }^{150}$. Y de nuevo la referencia directa a la dispensa del impedimento para el matrimonio de tía y sobrino, dándonos noticia sobre el gran coste, dada la mayor gravedad de tal impedimento: La dispensación le cuesta / mil escudos, y ha venido.

\section{II.3.G. En la confusión del Capitán}

El Capitan exclama extrañado: ¡Sobrino y primo! ¿Qué es esto, / y de cuándo acá nos vino? ${ }^{151}$

Pero en un encuentro a solas, el alférez va a sacar de dudas al Capitán allanando el camino

-Leonardo, a tus pretensiones / bien te puedo yo ayudar / pero no para pagar / tan malas dispensaciones / ¿Tu te casas con mi hermana? / No en balde Bárbara es.

-Sabe, señor, que he fingido / haber tu hermana querido, / y que el dinero he gastado / porque a Roma no ha llegado. / A doña Ángela di / palabra de casamiento ${ }^{152}$.

Significativa es la expresión del Capitán calificando la dispensa para su hermana de «mala» y aun de «bárbara», lo que muestra la consideración y opinión generalizada sobre el matrimonio en tercer grado colateral.

Un correo que llega al Capitán termina por decidir la situación: Su Majestad ha hecho merced al alférez por sus servicios y los del Capitán Fajardo su padre, de un hábito de Santiago y doscientos escudos de «entretenimiento».

149 Es clara la alusión a la consanguinidad en línea colateral, y a la fácil disculpa o dispensa que tal transgresión jurídica tiene.

150 Al fin se determinó a casar con su sobrino / y a casarme me forzó / para remediar me imagino.

151 Por un momento el Capitán parece también indeciso: —iPerdida la casa está! / Qué necio en dejarle fui / que mi hijo se llamase. ¿Cómo podré yo hacer / que Bárbara no se case?

152 A pesar de lo que cree Ángela, la dispensación para Bárbara no ha llegado, simplemente porque Leonardo gastándose el dinero, no la ha pedido. 


\section{II.3.H. Los pretendientes y el arbitraje del Capitán}

Los dos rivales han sido convocados por el Capitán al tratar del matrimonio conveniente para su sobrina, haciendo el papel de padre y señor. Del primer compareciente don Esteban noble y antiguo mayorazgo de Aragón, se hace saber que ha pedido en matrimonio a Ángela. El indiano pretendiente alega haberse declarado primero $^{153}$.

Finalmente lo que solicitan ambos a dos, es que no sea concedida la mano de la dama al otro, su rival ${ }^{154}$. El Capitán pronuncia su veredicto: Y yo digo / que no la daré a ninguno / de los dos.

\section{II.3.I. Bodas sin fraude y sin dispensa por fallo del Capitán}

Va a caer el telón con el desenlace retrasado hasta la última escena, una vez despejados los inconvenientes secundarios de los dos pretendientes rivales. El Capitán Fajardo constituido en el caso en autoridad familiar, y al mismo tiempo superior militar del galán cuyas nupcias ha de autorizar según costumbre española, va a dar su veredicto arbitral:

-Fallo que de Ángela es digno / el alférez don Leonardo / que con nombre de mi hijo / ha vivido en esta Corte ${ }^{155}$.

El Capitán conocedor de las claves del engaño nos devuelve a la realidad y sentencia dando de lado a cualquier dispensa innecesaria por inexistencia del supuesto, proporcionando marido a las dos damas: a Ángela el alférez que aunque ha dejado de ser hijo del Capitán, ha obtenido por méritos de ambos una encomienda, porque es entre ellos donde se da el amor verdadero ${ }^{156}$.

153 Octavio el indiano se enfrenta diciendo que pone impedimento al mismo, porque él la ha pretendido y servido primero, y que don Esteban amigo traidor se le ha adelantado procediendo en secreto. Adviértase en la línea del Derecho matrimonial la referencia al «impedimento» para la celebración del matrimonio; claro está que la razón con que se opone nada tiene de canónica.

154 -Yo sólo os pido / no la deis a don Esteban /

-Yo lo mismo / que no dándosela a Octavio / quedo contento.

155 A pesar del triunfo del amor, en este caso sobre el egoismo materno, Lope rinde tributo a su tiempo, vinculando el matrimonio a la autoridad familiar, en este caso al tío y hermano de la madre, que sustituye al paterfamilias.

156 Doña Bárbara que ya tenía por suyo al alférez, en revancha, se había negado no siendo bien nacido, a admitirlo por yerno. Pero la réplica la tiene el Capitán a mano y escrita: Que un hábito de Santiago / le honra el pecho / con doscientos escudos. 
Queda en la escena doña Barbara compuesta de boda y sin novio; pero para ella también su hermano ha dispuesto marido: No burlemos el vestido / Beltrán es muy hijodalgo / sólo le falta ser rico. / Tú lo eres ${ }^{157}$.

\section{BALANCE Y CONCLUSIONES}

\section{III.1. El tema de la consanguinidad y las dispensas}

La disposición canónica tridentina de que no se concediesen dispensas matrimoniales sino raras veces y esto con causa y gratis, y que en tercer grado (tios y sobrinos) nunca se dispense, a no ser entre grandes Príncipes y por una causa pública ${ }^{158}$, había llegado en poco tiempo a ser letra muerta, continuándose con la relajada y extendida práctica anterior que se había intentado corregir. Tales dispensas y sus aranceles fueron creciendo desmesuradamente ${ }^{159}$.

\section{III.1.A. Las causas en las dispensas canónicas de consanguinidad}

Aunque basada en el engaño que urde el alférez venido de Flandes, de ser sobrino de doña Bárbara y en consecuencia primo de Ángela, al proyectarse el matrimonio para cualquiera de las dos damas, forzosamente habría de obtenerse la correspondiente dispensa del impedimento en línea colateral, de cuarto grado para contraer con Ángela y de tercer grado para contraer con doña Barbara, siendo este último más difícil de obtener para lo que sería necesario alegar causas más graves. La cuestión de las causas para la dispensa no aparece para nada en la obra, mencionándose solo las expensas que conllevan tales dispensas ${ }^{160}$. Con ello nos ofrece la opinión generalizada para la que no contaban las causas aun en el caso más grave, pero sí las expensas o limosna requerida y los gastos que ocasionaba la expedición.

157 MAR ZUBIETA, loc. cit. p. 32: A Bárbara maestra en engaños y estratagemas Lope la une a Beltrán en matrimonio de conveniencia ante el que parece resignarse.

158 CONCILIO DE TRENTO, Ses. XXIV, De Reformatione, cap. 5.

159 Desempeñando en Roma en 1607 la función de protector de las iglesias de España, escribió el Cardenal Antonio Zapata en Memorial de agravios que se calculaba en unos seiscientos mil ducados al año los que salían de España para Roma, entre los que contaban las dispensas matrimoniales.

${ }^{160}$ Lo que ciertamente hace es distinguir bien entre dos situaciones, la de los primos que se dice atendible simplemente en razón del amor surgido, y la de tía y sobrino proyecto al que se califica de bárbaro por boca del Capitán Fajardo constituido en árbitro. 


\section{III.1.B. Una sutil actitud con lenguaje tecnico teatral}

Lope a pesar de sus fallos morales, no era al menos un descreido, ni mucho menos un opositor descarado de las actuaciones de la Iglesia; sin embargo en esta Comedia recoge con sutileza y habilidad una crítica que en su tiempo y sobre todo posteriormente se hacía a la Curia Romana sobre las dispensas matrimoniales, como sobre la concesión de otras gracias que conllevaban a veces fuertes expensas. Su actitud crítica se reduce a presentar los hechos sin poner en boca de sus personajes una crítica directa a dicha institución que empezaba a ser contestada por lo que suponía de ingresos para la Cámara Apostólica de la que el año 1615, es decir en breve iba a ser nombrado Procurador Fiscal en el Arzobispado de Toledo ${ }^{161}$.

Téngase en cuenta además que la obra está escrita en la época en que Lope ha entrado en la crisis que le llevará a la decisión de hacerse sacerdote.

Por sus técnicas teatrales, la sutil crítica que Lope hace en esta Obra de las dispensas canónicas de consanguinidad, no puede ser sino, indirecta, y más que de parlamentos de situaciones en que se coloca a los personajes de la comedia.

\section{III.2. Referencias a la institución de las dispensas}

Sin embargo los personajes no dejan de expresarse, sino de modo extenso y espacioso, si al menos con formulaciones concretas; lo más significativo de tales referencias a las «dispensas», es la repetición constante y machacona a lo largo de toda la Comedia de la obtención de las mismas y el pago de sus expensas.

\section{III.2.A. En el Acto segundo: seis referencias expresas a la «dipensación»}

Nada más comenzar el Acto segundo, el asesor aristócrata que acompaña a don Esteban el pretendiente aragonés, cuando se han enterado de la venida del militar, ha tratado de tranquilizar los celos que empiezan a despertarse en su patrocinado, porque el huésped lle-

161 LOPE DE VEGA, Epistolario: Su toma de posesión la comunica al Duque de Sessa hacia finales de 1616. "Hoy vino a mi casa el Secretario con el Auditor: diome el tal Secretario la provisión de Procurador fiscal de la Cámara apostólica». 
gado es su primo; a lo que don Esteban contesta con un dicho: Miel sobre hojuelas se llama / sobre parentesco amor ${ }^{162}$. Y entonces el experto consejero como una premonición del papel que va a ocupar el tema, previene:

- Si hay dispensación a cuenta / no es malo que los tengais.

La segunda vez en que se menciona la «dispensa», es poco después cuando Leandro descubre a Beltrán, que no sólo Ángela sino también Bárbara su madre se ha enamorado de él. Al preguntar a su pícaro asesor, qué ha de hacer si Bárbara pretende casarse con él, este le responde y aconseja:

-Haciendo que traigan dispensación/ pues entre tanto, podeis / hacer que de Ángela estéis/ en segura posesión ${ }^{163}$.

Cuando doña Bárbara se declara a Leonardo, la obtención de la dispensa, ya no se refiere a un supuesto en boca de personas ajenas como en los casos anteriores, sino que ahora es la propia interesada doña Bárbara la que habla de la gestión que va a hacer para poderse casar con su sobrino: Por una dispensación / quiero al momento enviar.

Este propósito y el conocimiento que se tiene implícito nos es descubierto cuando doña Bárbara afirma escuestamente su voluntad: Gástese toda mi hacienda ${ }^{164}$.

Ángela ha descubierto el engaño de su madre cuando mil ducados cuentas / y dispensación intentas / para casar con Leonardo, gestión que le demuestra que no es su hijo ${ }^{165}$.

En la violentísima discusión, Ángela que ha alcanzado la altura de su propia defensa de mujer, le amenaza con denunciar su intento de

162 Obsérvese que en este primer momento de la llegada del alférez y antes de tener noticia de su rivalidad amorosa, se nos ofrece la primera referencia a la «dispensa» en este caso puramente hipotética, aludiendo a aquellos nacientes celos.

163 Parece clara la referencia a una circunstancia de la dispensa, a saber la de su tardanza en la obtención, dado que había que hacer llegar la petición a Roma, tiempo que le dará espacio para gozar de la hija. Adviértase ademas que no se pone siquiera en duda la concesión de una dispensa tan grave cuya obtención se da por segura, lo que no es extraño pues se trata de una mera posibilidad.

164 Con ello se nos está diciendo que la interesada sabe la gravedad de la dispensa en el caso de matrimonio de tía con sobrino, y que conlleva unas fuertes expensas; esta referencia económica volverá a salir. No se critican tales emolumentos, sino que parecen aceptarse aunque perjudiquen su hacienda; pero sin embargo no se dejan de consignar.

165 En un paso más se habla ya de una cifra concreta, mil ducados, en el arancel para la dispensa confirmando que la dispensa que se solicita es la extrema y más costosa de tía y sobrino. 
¿DE CUÁNDO ACÁ NOS VINO? LOPE DE VEGA Y EL TABÚ DEL INCESTO

matrimonio oponiendo el impedimento más grave de los incestos, matrimonio de madre e hijo ${ }^{166}$. Y por quinta vez se nombra la «dispensación»: No importa / el traer dispensación; / que sabré poner un impedimento. La dispensación sería en consecuencia nula, según el impedimento denunciado si llegase a probarse.

Por sexta vez se hace referencia a la "dispensa», cuando se cierra el acto segundo con la reanudación de la relación de Leandro y Ángela al deshacerse el mal entendido. Al aclarar Leandro que su propósito de matrimonio con Bárbara es totalmente fingido, Ângela pregunta extrañada: ¿Cómo han ido por esta dispensación?

La respuesta de Leonardo es: No hayas miedo, / que vaya el dinero a Roma, / que irán los quinientos hoy. Con ello se da a entender que el costo de la dispensa entre primos carnales, es la mitad ${ }^{167}$.

\section{III.2.B. En el Acto Tercero: diez referencias a la «dispensación»}

Abren el Acto los pretendientes oficiales a los que los criados han aclarado, que el alférez con quien se va a casar es con doña Bárbara y que la "dispensación» está de camino, siendo ésta la séptima vez que se menciona la dispensa que ya se tiene por solicitada, en este caso para contraer el sobrino con la tía.

Cuando se discute del matrimonio de Ángela con don Esteban y con Octavio, por octava vez se menciona la dispensa que se pone en boca de Leandro. En un aparte se rie con Ángela: porque la dispensación / que ha de venir para ella / se ha pedido para ti. ${ }^{168}$.

En la escena siguiente los dos soldados al conocer la llegada del Capitán Fajardo, se ausentan rápidamente diciendo Leonardo: $M i$ señora a saber llego / de nuestra dispensación, con lo que hace la novena referencia a la misma.

Al hacerse presente el Capitán Fajardo, maravillado ante la belleza de su sobrina exclama: / Si fuera mozo yo / fueran dispensación estas razones.

166 Lope muestra sus conocimientos jurídicos de que en el caso al tratarse de una filiación ilegítima la prueba más contundente es la propia confesión extrajudicial de la madre de la que Ángela ha sido testigo.

${ }_{167} \mathrm{Sin}$ embargo hay que tener en cuenta que la necesidad de dispensa para este matrimonio, es también una ficción, con lo que según va despejándose el enredo va reduciéndose la referencia a la dispensa hasta quedar en nada. 
-No faltan por acá dispensaciones, ha respondido Ángela. Pero de nuevo el Capitán reitera sus cumplidos con mención de nuevo de la dispensa:

-Que como os dije, si otra edad tuviera, / nuestra dispensación no se excusara.

Por tres veces en esta escena del encuentro de tío y sobrina, se menciona la «dispensa» de consanguinidad, con lo que se tiene la referencia duodécima de esta institución canónica.

Cuando la pareja de soldados reconciliados en su encuentro con el Capitán vuelven a la casa de Barbara, el alférez se pregunta con una decimo tercera referencia:

- ¿Si habrá de Roma venido / aquella dispensación?

El Capitán va a dar su veredicto poniendo en orden la casa de su hermana, produciéndose entonces la decimocuarta mención de la dispensación de la que se dice que a Bárbara la dispensación le cues$\mathrm{ta} /$ mil escudos, $y$ ha venido ${ }^{169}$.

El Capitán sale de su perplejidad, cuando se le hace saber que son tía y sobrina las que pretenden al Alférez al que creía en trámites para casarse con Bárbara, y se dispone a ayudale en su pretensión:

-Leonardo, bien te puedo yo ayudar / pero no para pagar / tan malas dispensaciones/ no en balde Bárbara es ${ }^{170}$.

El alférez después de declarar la ficción de su enamoramiento de doña Barbara y que

- A doña Ángela di / palabra de casamiento; confiesa también el engaño de la dispensa y que el dinero he gastado / porque a Roma no ha llegado.

Son la decimaquinta y decimasexta mención de la dispensa.

168 Suena a ironía esta referencia de Leandro conocedor de que tal dispensa no es necesaria, con lo que el enredo de la obra se está sosteniendo en una clave vacía de contenido.

169 Pero además al confesar Ángela a su tío su amor por el alférez se ofrece también la referencia al impedimento de consanguinidad: Amor a amar me previno, / que ser la sangre tercera / disculpa mi desatino, en clara la alusión al cuarto grado de consanguinidad en línea colateral, y a la fácil disculpa o dispensa que tal transgresión jurídica tiene.

170 Clara referencia a la boda con su hermana, aludiendo con ello haber sido la costumbre de los pueblos germánicos, la que vulgarizó tal práctica, insólita y escandalosa en occidente. 
¿DE CUÁNDO ACÁ NOS VINO? LOPE DE VEGA Y EL TABÚ DEL INCESTO

\section{III.3. Conclusiones}

1. Las prescripciones del Concilio de Trento, concluido cuando Lope era estudiante sobre la concesión de las dispensas de consanguinidad no tendrían lugar en los casos que Lope presenta, debido a la inexistencia en ambos casos de consanguinidad.

2. La ausencia de causa, sobre todo en la situación excepcional del tercer grado que la requeriría muy grave, la muy endeble del amor surgido en la de cuarto grado, y el silencio sobre las mismas a pesar de que Lope hace hablar tantas veces a sus personajes de dichas dispensas, es ya una declaración implícita de que poco o nada cuentan en la apreciación vulgar, para la cual la dispensa solo requeriría su solicitud y el pago de las expensas.

3. En cuanto a los costes que suponían las dispensas de parentesco de los cónyuges, hay que recordar que junto a la concesión de una gracia no evaluable en dinero, la Curia Romana tenía establecidos sus exacciones (taxas por gestión, composición para causas pías y un impuesto según la gravedad). En la Comedia en el caso más grave de tía y sobrino se mencionan mil escudos o ducados, que en el de la dispensa de primos se cifra en la mitad. La crítica solapada de Lope no parece se haga a la falta de gratuidad, sino tal vez al montante de las expensas en el caso más grave, pues se dice suponer una parte de la hacienda.

4. Otra de las críticas implícitas es la del tiempo de demora en la concesión de la dispensa, al tener que acudir a la Curia Papal; en algunas naciones se había concedido esta facultad de dispensar la consanguinidad a los Obispos, y ciertamente por esta época se concede a los Misioneros en los paises de evangelización. De nuevo la crítica es sutil, sin queja alguna contentándose con la constatación de la posible demora.

5. También hay que señalar la inanidad e inoperancia consiguiente de la dispensa, que se pone como clave de todo el enredo de la Comedia, y que a pesar de todo levanta celos, engaños, luchas y discusiones, y toda la trama de la obra; es ella misma un engaño, por no tener siquiera la mínima base de existencia de impedimento de consanguinidad en ninguno de los casos.

6. Finalmente aunque en una consideración superficial no parecería caber la existencia de una crítica de Lope de Vega, dada la falta de parlamentos en que de modo directo se cuestione la institución de la dispensa del impedimento de consanguinidad; pero lo cierto es que 
Lope maestro en el arte dramático hace su comentario crítico a través de las situaciones y actitudes de los personajes: no sólo son los propios interesados, sino aun ajenos como los otros pretendientes oficiales, el Capitán y el soldado Beltrán, sin que falten por otra parte en las expresiones breves referencias a los costes, la demora, y aun a la barbarie que se da en la dispensa de tía y sobrino. 